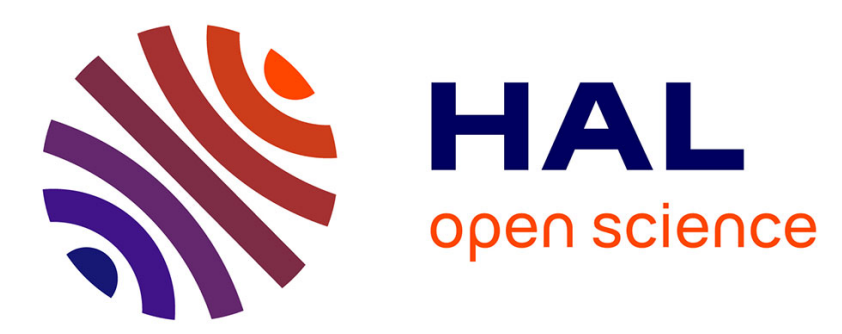

\title{
Elevation effects on the carbon budget of tropical mountain forests (S Ecuador): The role of the belowground compartment
}

\author{
C Leuschner, Gerald Moser
}

\section{- To cite this version:}

C Leuschner, Gerald Moser. Elevation effects on the carbon budget of tropical mountain forests (S Ecuador): The role of the belowground compartment. Global Change Biology, 2011, 17 (6), pp.2211. 10.1111/j.1365-2486.2010.02367.x . hal-00609002

\section{HAL Id: hal-00609002 https://hal.science/hal-00609002}

Submitted on 17 Jul 2011

HAL is a multi-disciplinary open access archive for the deposit and dissemination of scientific research documents, whether they are published or not. The documents may come from teaching and research institutions in France or abroad, or from public or private research centers.
L'archive ouverte pluridisciplinaire $\mathbf{H A L}$, est destinée au dépôt et à la diffusion de documents scientifiques de niveau recherche, publiés ou non, émanant des établissements d'enseignement et de recherche français ou étrangers, des laboratoires publics ou privés. 


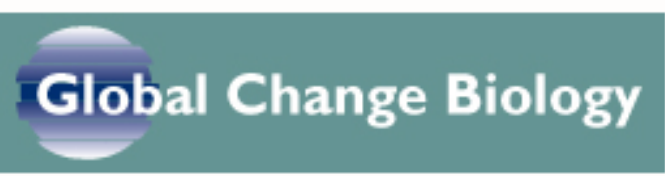

\section{Elevation effects on the carbon budget of tropical mountain forests (S Ecuador): The role of the belowground compartment}

\begin{tabular}{|c|c|}
\hline Journal: & Global Change Biology \\
\hline Manuscript ID: & GCB-10-0686 \\
\hline Wiley - Manuscript type: & Primary Research Articles \\
\hline $\begin{array}{r}\text { Date Submitted by the } \\
\text { Author: }\end{array}$ & 19-Aug-2010 \\
\hline Complete List of Authors: & $\begin{array}{l}\text { Leuschner, C; University of Goettingen, Plant Ecology } \\
\text { Moser, Gerald; University of Goettingen, Plant Ecology }\end{array}$ \\
\hline Keywords: & $\begin{array}{l}\text { tropical montane forest, belowground biomass, root production, } \\
\text { wood increment, root/shoot ratio }\end{array}$ \\
\hline Abstract: & $\begin{array}{l}\text { Carbon storage and sequestration in tropical mountain forests and } \\
\text { their dependence on elevation and temperature are not well } \\
\text { understood. In an altitudinal transect study in the South Ecuadorian } \\
\text { Andes, we tested the hypotheses that (i) aboveground net primary } \\
\text { production (ANPP) decreases continuously with elevation due to } \\
\text { decreasing temperatures, whereas (ii) belowground productivity } \\
\text { (BNPP) remains constant or even increases with elevation due to a } \\
\text { shift from light to nutrient limitation of tree growth. In five tropical } \\
\text { mountain forests between } 1050 \text { and } 3060 \text { m a.s.I., we investigated } \\
\text { all major above- and belowground biomass and productivity } \\
\text { components, and the stocks of soil organic carbon (SOC). Leaf } \\
\text { biomass, stemwood mass and total aboveground biomass (AGB) } \\
\text { decreased by } 50 \text { to } 70 \% \text {, ANPP by about } 70 \% \text { between } 1050 \text { and } \\
3060 \text { m, while stem wood production decreased } 20 \text { fold. Coarse and } \\
\text { large root biomass increased slightly, fine root biomass } 4 \text { fold, while } \\
\text { fine root production (minirhizotron study) roughly doubled between } \\
1050 \text { and } 3060 \text { m. The total tree biomass (above- and } \\
\text { belowground) decreased from about } 320 \text { to } 175 \text { Mg dry mass ha-1, } \\
\text { total NPP from ca. } 13.0 \text { to } 8.2 \text { Mg ha-1 yr- } 1 \text {. The } \\
\text { belowground/aboveground ratio of biomass and productivity } \\
\text { increased with elevation indicating a shift from light to nutrient } \\
\text { limitation of tree growth. We propose that, with increasing } \\
\text { elevation, an increasing nitrogen limitation combined with } \\
\text { decreasing temperatures causes a large reduction in stand leaf area } \\
\text { resulting in a substantial reduction of canopy carbon gain toward } \\
\text { the alpine tree line. We conclude that the marked decrease in tree } \\
\text { height, AGB and ANPP with elevation in these mountain forests is }\end{array}$ \\
\hline
\end{tabular}




\section{SCHOLARONE' Manuscripts}

caused by both a belowground shift of $\mathrm{C}$ allocation and a reduction in C source strength, while a temperature-induced reduction in $\mathrm{C}$ sink strength (lowered meristematic activity) seems to be of secondary importance. 


\section{Elevation effects on the carbon budget of tropical mountain forests ( $S$}

\section{Ecuador): The role of the belowground compartment}

3

6 Gerald Moser $^{1}$, Christoph Leuschner ${ }^{1 *}$, Dietrich Hertel ${ }^{1}$, Sophie Graefe ${ }^{1}$, Nathalie

7 Soethe ${ }^{2}$, Susanne Iost $^{3}$

$10{ }^{1}$ Plant Ecology, Albrecht von Haller Institute for Plant Sciences, University of

11 Göttingen, Untere Karspüle 2, 37073 Göttingen, Germany.

$12{ }^{2}$ Plant Nutrition, Humboldt University of Berlin, Unter den Linden 6, D-10099 Berlin,

13 Germany

$14{ }^{3}$ Institute for World Forestry, Johann Heinrich von Thünen-Institut (vTI), Federal

15 Research Institute for Rural Areas, Forestry and Fisheries, Leuschnerstr. 91, D-21031

16 Hamburg, Germany,

18 *Corresponding author: cleusch@gwdg.de, Tel: 0049551 395718, Fax: 0049551

$19 \quad 395701$

Keywords: aboveground biomass, belowground biomass, fine root production, net 


\section{AbSTRACT}

2 Carbon storage and sequestration in tropical mountain forests and their dependence on 3 elevation and temperature are not well understood. In an altitudinal transect study in the 4 South Ecuadorian Andes, we tested the hypotheses that (i) aboveground net primary 5 production (ANPP) decreases continuously with elevation due to decreasing 6 temperatures, whereas (ii) belowground productivity (BNPP) remains constant or even 7 increases with elevation due to a shift from light to nutrient limitation of tree growth. In 8 five tropical mountain forests between 1050 and $3060 \mathrm{~m}$ a.s.l., we investigated all major 9 above- and belowground biomass and productivity components, and the stocks of soil 10 organic carbon (SOC). Leaf biomass, stemwood mass and total aboveground biomass 11 (AGB) decreased by 50 to 70\%, ANPP by about 70\% between 1050 and $3060 \mathrm{~m}$, while 12 stem wood production decreased 20fold. Coarse and large root biomass increased 13 slightly, fine root biomass 4 fold, while fine root production (minirhizotron study) 14 roughly doubled between 1050 and $3060 \mathrm{~m}$. The total tree biomass (above- and 15 belowground) decreased from about 320 to $175 \mathrm{Mg}$ dry mass ha $^{-1}$, total NPP from ca. 1613.0 to $8.2 \mathrm{Mg} \mathrm{ha}^{-1} \mathrm{yr}^{-1}$. The belowground/aboveground ratio of biomass and 17 productivity increased with elevation indicating a shift from light to nutrient limitation 18 of tree growth. We propose that, with increasing elevation, an increasing nitrogen 19 limitation combined with decreasing temperatures causes a large reduction in stand leaf 20 area resulting in a substantial reduction of canopy carbon gain toward the alpine tree 21 line. We conclude that the marked decrease in tree height, AGB and ANPP with 22 elevation in these mountain forests is caused by both a belowground shift of $\mathrm{C}$ 23 allocation and a reduction in $\mathrm{C}$ source strength, while a temperature-induced reduction in C sink strength (lowered meristematic activity) seems to be of secondary importance. 


\section{INTRODUCTION}

2 Tropical rainforests occupy only some $12 \%$ of the terrestrial surface but contain about

$355 \%$ of the biomass (Grace \& Meir 2009). An accurate characterization of carbon stores

4 and net primary production in tropical forests will be fundamental for realistic global

5 and regional $\mathrm{C}$ budgets and for predicting how these will be affected by the changing

6 climate. Not only forest conversion, but also changes in temperature, $\left[\mathrm{CO}_{2}\right]$ and rainfall

7 may significantly affect the $\mathrm{C}$ sequestration potential of tropical forests (Grace et al. 8 1995).

9 There is no simple approach for obtaining information on the possible future response

10 of tropical old-growth rainforests to the expected changes in temperature, rainfall and 11 atmospheric $\left[\mathrm{CO}_{2}\right]$. Field manipulation studies may help to investigate forest responses 12 to altered rainfall and $\left[\mathrm{CO}_{2}\right]$ (e.g. da Costa et al. 2010), but they are hardly practicable 13 for studying long-term effects of elevated temperature on tropical forests. One source of 14 indirect information can be transect studies along latitudinal or altitudinal temperature

16 functioning in different climates. Even though most gradient studies are suffering from the fact that one or more environmental factors covary with the target variable, valuable insights into the temperature dependence of productivity and carbon cycling in forests have been achieved by comparing $\mathrm{C}$ pools and fluxes in forests differing in mean temperature (e.g. Clark et al. 2001; Luyssaert et al. 2007).

The majority of studies assessing $\mathrm{C}$ pools and $\mathrm{C}$ sequestration in tropical moist forests have been conducted in lowland forests (e.g. Clark et al. 2003; Feeley et al. 2007), while the $\mathrm{C}$ stores of tropical mountain forests are less well known. The decrease in tree size with elevation indicates a reduction of the biomass $\mathrm{C}$ pool towards higher altitudes, whereas reduced decomposition rates may cause higher amounts of soil organic carbon (SOC) in tropical montane and upper montane forests as compared to lowland stands (e.g. Grubb et al. 1963; Tanner 1981; Schawe et al. 2007).

Clark et al. (2001) synthesized the available data on the biomass and productivity of tropical forests based on published data for 39 forest sites. While numerous studies have measured aboveground biomass, stem wood increment and fine litterfall, only very limited or no data exist on other aboveground NPP components such as leaf herbivory, organic leachates or the release of VOCs. More critical, however, is the scarcity of information on belowground biomass and belowground NPP (BNPP). The biomass of 
1 coarse and large roots (i.e. roots $>2 \mathrm{~mm}$ in diameter) was measured at very few sites 2 only and typically by excavating a few trees or digging a few monoliths (Clark et al. 3 2001). The data base is more comprehensive for fine root biomass ( $<2 \mathrm{~mm}$ in diameter) 4 with 32 and 19 investigated tropical forest sites listed in the reviews of Vogt et al. 5 (1996) and Jackson et al. (1996). A recent data compilation by Finér et al. (in press) 6 contains fine root biomass data from 83 tropical forest stands, mostly from lowland 7 sites. For Amazonian forests, Houghton et al. (2001) report a mean root biomass value 8 of $21 \%$ (range $13-26 \%$ ) of aboveground live tree biomass.

9 Only a small number of studies attempted to quantify fine root production (e.g. 10 Espeleta \& Clark 2007; Metcalfe et al. 2008), but often with inadequate methods. 11 Empirical data on the coarse root increment of tropical forests are virtually lacking. 12 Clark et al. (2001) proposed a range for the belowground net primary production of 13 tropical forests of 20 to $120 \%$ of aboveground NPP, which demonstrates the importance 14 of BNPP in productivity estimates. Such wide ranges in estimated root production 15 reflect the fact that our knowledge on BNPP in tropical forests is very limited causing 16 large uncertainties about carbon balance and $\mathrm{C}$ turnover in these forests.

17 In this study along a 2000-m elevation transect in South Ecuador, we collected a 18 unique dataset on above- and belowground biomass fractions and related carbon pools, 19 SOC, and above- and belowground productivity of five mountain forest stands situated 20 at elevations between 1000 and $3000 \mathrm{~m}$ a.s.l. The main focus is on root biomass and root productivity, the fractions with largest uncertainties.

22 Based on earlier work in the area (Leuschner et al. 2007; Moser et al. 2007; Graefe et 23 al. 2008a, b), we hypothesized that (i) aboveground NPP decreases continuously with 24 elevation driven by the more or less constant temperature decrease, whereas (ii) 25 belowground NPP remains constant or increases with altitude, reflecting a change in 26 resource limitation from predominant light limitation at low elevations to an increasing 27 nutrient limitation at high elevations. Several other environmental parameters were also 28 measured along this transect for identifying putative underlying causes of elevational 29 change in biomass and productivity.

\section{MATERIAL AND MethodS}

\section{Study sites}


We installed five permanent forest plots between $1050 \mathrm{~m}$ and $3060 \mathrm{~m}$ a.s.l. at a 2 maximum distance to each other of $30 \mathrm{~km}$ in the South Ecuadorian provinces of 3 Zamora-Chinchipe and Loja. The lowermost stands \#1 and 2 are within the Podocarpus

4 National Park at pre-montane elevation close to the park entrance at Bombuscaro, south 5 of the provincial capital Zamora (\#1: S $04^{\circ} 06^{\prime} 54^{\prime \prime}$, W 78 $58^{\circ} 20^{\prime \prime}$; \#2: S04 $06^{\circ} 42^{\prime \prime}$, W

$\left.678^{\circ} 58^{\prime} 20^{\prime \prime}\right)$. Stands \#3 and 4 (montane elevation) are located in the adjacent Reserva

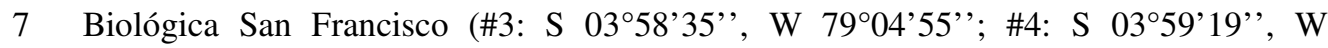

$\left.87^{\circ} 04^{\prime} 55^{\prime \prime}\right)$. Stand \#5 is a stunted upper montane forest located in the Cajanuma area of 9 the national park (S $04^{\circ} 06^{\prime} 771^{\prime \prime}$, W $\left.79^{\circ} 10^{\prime} 58^{\prime \prime}\right)$. Patches of treeless alpine paramo 10 vegetation are found about $200 \mathrm{~m}$ upslope of this stand (Fig.1).

11 The stands are situated on moderately steep slopes facing northeast to northwest, except for stand \#2 (10 inclination, Table 1). Study plots of $400 \mathrm{~m}^{2}$ size were selected in forest areas with no or only minimal signs of human influence (as indicated by charcoal, stumps, or the presence of light-demanding pioneer trees). We used the floristic and physiognomic classification system of Balslev \& Øllgaard (2002) to select forest patches that were representative for the forest vegetation of the respective elevation. Parts of the stand without larger canopy gaps and unaffected by topsoil disturbance due to animal activity were selected for study. Since pedological investigations in Ecuadorian mountain forests had revealed that the soil properties can vary significantly even over short distances, we chose a relatively small plot size of 20 m x 20 m. Large plots may thus include stands of considerable structural heterogeneity.

The extremely high need of labour for quantifying the root biomass and production did not allow to study more than five stands in the transect. To cope with the problems that arise from the lack of repetition at the stand level and in order to place our results in a broader pan-tropical context, we completed our study with a meta-analysis of altitudinal transect studies in tropical mountain forests.

In the study region on the eastern slopes of the Andes, precipitation shows a principal increase with elevation from $1050 \mathrm{~m}$ to $3060 \mathrm{~m}$ (P. Emck and M. Richter, unpublished data). The soil types change along the gradient due to changes in climate, bedrock type and hydrology (Table 1). The mineral topsoil is moderately to highly acidic with $\mathrm{pH}\left(\mathrm{CaCl}_{2}\right)$ values between 2.9 and 3.9, while the organic top layers have higher $\mathrm{pH}$ values and base saturations (Iost 2007). The transect is characterized by a general, but 
1 in the densely rooted uppermost organic horizons markedly decreased between 1050

2 and $3060 \mathrm{~m}$ as is evidenced by decreasing gross $\mathrm{N}$ mineralization rates and extractable

3 concentrations of inorganic $\mathrm{N}\left[\mathrm{N}_{\text {inorg }}\right]$, but increasing $\mathrm{C} / \mathrm{N}$ ratios of the organic material

4 (Iost 2007; Table 1). Such a trend is absent, or even reversed, in the mineral topsoil.

5 However, gross $\mathrm{N}$ mineralization rate and $\left[\mathrm{N}_{\text {inorg }}\right]$ were by a magnitude higher in the

6 organic top layers than in the mineral soil.

7 Along the 2000-m elevation transect, a characteristic change in tree species

8 composition takes place. Only canopy trees belonging to the family of Melastomataceae

9 occurred at all elevations; another five plant families were present at least in four of the

10 five stands. Most other families showed clear preferences for the pre-montane, montane

11 or upper montane belt (J. Homeier, pers. comm.).

12

\section{Estimation of aboveground biomass and production}

The forest structure and tree biometric data were investigated in samples of 80 trees per stand that reached at least the lower canopy, without defining a minimum diameter at breast height (DBH, at $1.3 \mathrm{~m}$ ). These 80 trees covered an area of $827 \mathrm{~m}^{2}$ in stand \#1, and of 360, 343, 290 and $96 \mathrm{~m}^{2}$ (in horizontal projection) in the stands \#2, 3, 4 and 5, respectively, reflecting the increase in stem density (from 968 to $8317 \mathrm{ha}^{-1}$ ) with 19 elevation. The smallest DBH of canopy trees was $5 \mathrm{~cm}$ at $1050 \mathrm{~m}$ and $3 \mathrm{~cm}$ at $3060 \mathrm{~m}$. 20 Along the transect from 1000 to $3000 \mathrm{~m}$, mean DBH decreased to about 40\%, canopy height to about $30 \%$, and leaf area index (LAI) to about $35 \%$ of its value at $1000 \mathrm{~m}$ 22 (Table 1). For more details on stand structure see Moser et al. (2008).

Total aboveground tree biomass was estimated with allometric equations for the 80 canopy trees per stand based on measured DBH, tree height and wood specific gravity.

25 We ignored understorey trees and shrubs, and standing or lying dead trunks (see Wilcke et al. 2005) since understorey biomass in mature tropical moist forests may typically comprise less than 3\% of aboveground biomass (Brown 1997).

28 We used the pan-tropical allometric equation of Chave et al. (2005) for wet tropical forests. This equation estimates the total aboveground tree biomass including leaves, twigs, branches, bark and boles, and bases on data of 2410 harvested trees from all over the tropics.

32 We tested the applicability of this allometric equation to our stands in small samples 33 of three recently wind-thrown tree individuals per each stand, which were analyzed for 
1 stem length, DBH, wood volume and wood specific gravity. The biomass figures were

2 sufficiently close to the predictions of the Chave equation which calculates the total 3 aboveground live biomass of a tree from:

4

5

6

$$
\text { (1) } A G B_{\text {tree }}=\exp \left(-2.557+0.940 \ln \left(\sigma D^{2} H\right)\right)
$$

where $A G B_{\text {tree }}$ is the single-tree aboveground biomass (kg per tree), $D$ is DBH $(\mathrm{cm}), H$ is tree height $(\mathrm{m})$ and $\sigma$ is wood specific gravity $\left(\mathrm{g} \mathrm{cm}^{-3}\right)$, the latter being measured in a subsample of 20 trees per plot by stem wood coring. We used stand-level means of wood density for the remaining 60 trees because we found for $\sigma$ a coefficient of variation among the species of a stand of only $15-20 \%$. Total aboveground biomass of the stand (AGB) was calculated as the sum of the 80 trees of a plot. To obtain wood biomass (trunks, branches, twigs), stand leaf biomass $\left(\mathrm{B}_{\mathrm{l}}\right)$ was determined independently (see below) and subtracted from AGB.

Stand leaf biomass was calculated from the measurement of annual leaf litter production. Twelve litter buckets per stand equipped with $50 \mathrm{~cm} \times 50 \mathrm{~cm}$ gauze sheets of $1 \mathrm{~mm}$-mesh width were positioned randomly in the $400 \mathrm{~m}^{2}$ plots. During the $1-\mathrm{yr}$ measuring period, the litter was collected every three weeks in the stands \#1 and 2, where decomposition rates were high, and every six weeks in the three other stands, starting on May 26, 2003. For estimating $\mathrm{B}_{1}$, only the tree leaf fraction was considered. The small fractions of epiphyte leaves, leaves of understorey plants (including bamboo), reproductive organs (flowers and fruits), twigs and the residual litter were determined separately; they were included in the fine litter total.

We assumed that leaf growth and leaf abscission occurred at similar rates in the study year, i.e. that leaf biomass in May 2003 and in May 2004 were equal. This would imply that annual leaf litter production equalled annual leaf biomass production.

Leaf lifespan was recorded by establishing leaf survivorship curves for leaf populations on 10-15 trees per stand that were selected randomly in the plots. In all cases, small individuals (1.5 to $5 \mathrm{~m}$ high) of canopy tree species were selected since continuous access to the upper canopy of large trees could not be provided. In the stands $\# 1$ to 4 , these trees were part of the understorey or lower canopy strata, whereas they formed the uppermost canopy layer in stand \#5. In May 2003, 24 twigs were marked in the 10-15 trees of each plot resulting in 254-666 leaves observed per stand. Every three 
1 to six weeks, the number of young, mature and dead leaves per marked twig was 2 counted. We registered the survivorship of all leaves of the first census until the last leaf 3 was shed. In the stands \#3-5, the average lifespan of many leaves exceeded the 4 observation period of 19 months. In these cases, the average leaf lifespan in the leaf 5 population was obtained from linear extrapolation of the survivorship curves. Stand leaf 6 biomass (in $\mathrm{Mg} \mathrm{ha}^{-1}$ ) was then calculated from equation (2):

\section{Measurement of root biomass and estimation of root production}

The biomass of coarse and large roots (all roots $>2 \mathrm{~mm}$ in diameter) was determined in 12-16 soil pits $(40 \mathrm{~cm} \times 40 \mathrm{~cm})$ per stand that were dug to $60 \mathrm{~cm}$ soil depth. The position of the pits was chosen randomly in the stands for obtaining stand-level estimates of root biomass in the larger root diameter classes. Minimum stem distance was $1 \mathrm{~m}$ to stay outside the reach of root buttresses and adventitious roots. Consequently, our stand-level averages are most likely underestimates of coarse and large root biomass (termed 'coarse roots' hereafter) because the root stocks of the trees were not excavated. The root mass (biomass and necromass) in the soil pits was extracted in steps of $10 \mathrm{~cm}$-thick soil layers in the organic layer and the mineral soil. In the laboratory, all coarse roots were washed and dried at $70{ }^{\circ} \mathrm{C}$ to constant dry mass.

For analysing the bio- and necromass of roots $<2 \mathrm{~mm}$ in diameter (fine roots) in the five stands, soil coring was conducted from March to May 2003 in soil profiles of 30 $\mathrm{cm}$ depth (organic layers and mineral soil, $\mathrm{n}=20$ per stand). A preliminary 
1 investigation of a smaller number of soil cores to $60-80 \mathrm{~cm}$ depth had shown that at 2 least $75 \%$ of the profile total of tree fine root biomass was contained in the organic 3 layers and the mineral soil to $30 \mathrm{~cm}$ depth. Consequently, the fine root densities in the

4 subsoil were very low. In this study, only the profile totals of fine root biomass from the 5 organic layers and the mineral soil to $30 \mathrm{~cm}$ depth are considered.

6 Root sampling was conducted with a $33 \mathrm{~mm}$ wide and $50 \mathrm{~mm}$ long steel corer. The 7 soil material was stored at $4{ }^{\circ} \mathrm{C}$ in the laboratory of the Estación Científica San 8 Francisco, where processing took place within 30 days. Fine root biomass and 9 necromass were separated under a microscope according to the procedure described by 10 Leuschner et al. (2001). In this paper, only fine root biomass will be considered. For 11 details on fine root necromass and root decomposition see Moser et al. (in press).

12 Fine root production $\left(\mathrm{P}_{\mathrm{FR}}\right)$ was estimated from minirhizotron observation of fine root 13 birth, growth and death in the five stands; this technique was found to give more reliable 14 data on $\mathrm{P}_{\mathrm{FR}}$ than other methods (Graefe et al. 2008a, Moser et al. in press). In June 15 2005, we installed 10 transparent minirhizotron tubes with an external diameter of 70 $16 \mathrm{~mm}$ at random positions in each of the five stands. They were placed vertically to the 17 soil surface and installed to a depth of ca. $40 \mathrm{~cm}$ wherever possible.

18 In this study, only the uppermost $10 \mathrm{~cm}$ of the tube in the organic layers or mineral 19 topsoil were analyzed for fine root dynamics, because the very high stone content of the 20 mineral soil in the lowermost stand did not allow a deeper penetration of the tubes into the soil at several measuring locations. For monitoring root growth, a root scanner 22 system (CI-600 Root Growth Monitoring System, CID Inc., USA) was inserted into the 23 tubes at monthly intervals from June 2005 to January 2007. However, only data from 24 November 2005 onwards were considered in the analysis in order to minimize errors in 25 root production estimation caused by disturbance effects during tube installation. The 26 images were analyzed for changes in fine root length using the software WinRHIZO 27 Tron (Régent, Quebec, Canada). Relative increases and relative losses in root length 28 (unit: $\mathrm{cm} \mathrm{cm}^{-1} \mathrm{mo}^{-1}$ ) were calculated by relating root length increase or root length loss 29 between two observation dates to the root length visible at the previous measuring date 30 (Graefe et al. 2008a). By relating this data to 12 months, we estimated the annual root 31 length production of the visible fine root population in the rhizotron tubes (Nadelhoffer 32 2000). By means of the root productivity in the uppermost $10 \mathrm{~cm}$ of the soil and the 
1 standing biomass of the organic layers and the mineral topsoil $(0-30 \mathrm{~cm})$ we estimated

2 the fine root production in the soil profile $\left(\mathrm{P}_{\mathrm{FR}}\right)$.

3 For two reasons we assume that the $\mathrm{P}_{\mathrm{FR}}$ figure for the uppermost stand $(3060 \mathrm{~m})$ 4 derived from the minirhizotron data is an overestimate (Moser et al., in press). 5 Consequently, we replaced these values by a lower production figure that was 6 calculated by extrapolating the $\mathrm{P}_{\mathrm{FR}}$ data of the stands \#1-4 to $3060 \mathrm{~m}$. The first reason is 7 that root growth and death events observed in the minirhizotron tubes in the uppermost $810 \mathrm{~cm}$ of the soil profile may not be representative for the root mass in the entire soil 9 profile, in particular in the very thick, acidic and moist organic soils at $3060 \mathrm{~m}$. Second, $10 \mathrm{P}_{\mathrm{FR}}$ could be overestimated at $3060 \mathrm{~m}$ because fine root growth is slower in lower 11 temperatures at higher elevations with the consequence that fine root initiation and 12 death in high-elevation forests require longer periods for reaching a steady state at the 13 tube surfaces than in low-elevation forests (Graefe et al. 2008b). Thus, slow-growing 14 roots at $3060 \mathrm{~m}$ could still have been in the recovery phase after the disturbance by the 15 tube installation. As a consequence, all subsequent calculations were conducted with the 16 extrapolated (conservative) fine root production $\left(4.7 \mathrm{Mg} \mathrm{ha}^{-1} \mathrm{yr}^{-1}\right)$ and total BNPP 17 values $\left(5.1 \mathrm{Mg} \mathrm{ha}^{-1} \mathrm{yr}^{-1}\right)$ for the $3060 \mathrm{~m}$ stand.

18 Coarse root production was measured with 20 dendrometer tapes per stand, mounted 19 on superficially growing coarse and large roots at diameters in the range 20-300 mm. 20 The tapes were read every six weeks, starting in May 2003. From diameter increment, we calculated the relative volume increment of each measured coarse root segment. Based on the coarse root biomass data obtained in the soil pits, stand totals of coarse root production were calculated (for details see Soethe et al. 2006a, b).

For expressing the biomass stocks and productivity components in terms of carbon, we analyzed the $\mathrm{C}$ concentration in sub-samples of all biomass fractions using a $\mathrm{CN}$ auto-analyzer (Vario EL III, elementar, Hanau, Germany) at the University of Göttingen (live fine and coarse roots, stem wood, fine root and leaf litter: $\mathrm{n}=20$, leaves: $\mathrm{n}=10-20$ 28 per stand).

\section{Measurement of soil organic carbon pools}

31 Eighteen soil cores were extracted at random positions in each stand in April 2004; the organic layer horizons were sampled using a $20 \mathrm{~cm} \times 20 \mathrm{~cm}$ wooden frame. The two organic layer horizons separated during soil sampling were designated as Oi (recently 
1 shed litter) and OeOa (strongly decomposed material with no visible structure). The

2 latter horizon consisted of small aggregates of humic substances and a high density of

3 fine root mass. Mineral soil was sampled to a depth of $30 \mathrm{~cm}$ below the transition zone

4 from the organic OeOa to the mineral topsoil. At the majority of coring locations, the

5 bedrock was reached at this depth. The samples were taken with a soil auger of $10 \mathrm{~cm}$ in

6 diameter. For each horizon and stand, six composite samples were assembled from three

7 individual samples each. These composite samples were subject for further analysis.

8 During soil sampling organic layer thickness was determined at each sampling point.

9 The samples were transported in polyethylene (PE) bags to the laboratory of the ECSF

10 and weighed for the determination of soil dry mass. The soil was then homogenized by

11 hand, which involved cutting of the litter layer in approximately $1 \mathrm{~cm} \times 1 \mathrm{~cm}$ pieces.

12 Stones, coarse woody debris and roots were removed carefully. Subsequently, the samples were transported to Germany via airplane within one week and immediately processed in the laboratories of the Institute for Soil Science and Site Ecology of Dresden University of Technology. During transport the samples were cooled to approximately $10{ }^{\circ} \mathrm{C}$ and care was taken that the temperature of the samples did not rise above the average temperature at the location of origin. We did not freeze the soil material because we expected that such a treatment would affect the soil microbial

Due to the nature of the bedrocks and the low $\mathrm{pH}$ of the mineral soil, the soils were free of carbonate. Thus, all carbon in the soil is organic $\mathrm{C}$ (SOC). For the determination of SOC an aliquot of each sample was dried $\left(40{ }^{\circ} \mathrm{C}\right.$ mineral soil; $60{ }^{\circ} \mathrm{C}$ organic layers) and milled (vibratory disc mill RS 100, Retsch, Germany). Organic layer samples were milled at $700 \mathrm{rpm}$ for $45 \mathrm{~s}$ and mineral soil samples at $1400 \mathrm{rpm}$ for $60 \mathrm{~s}$. After milling, the samples were dried again overnight at $40{ }^{\circ} \mathrm{C}$. The amount of carbon was determined by a thermal conductivity sensor after complete dry combustion at $1150{ }^{\circ} \mathrm{C}$ (CNSAnalyzer vario EL III, elementar, Hanau, Germany). The stocks of SOC were expressed in $\mathrm{kg} \mathrm{ha}^{-1}$ per horizon and as profile totals (organic layers plus mineral soil to $30 \mathrm{~cm}$ depth).

The salt-extractable inorganic nitrogen concentration $\left[\mathrm{N}_{\text {inorg }}\right]$ was analysed in $\mathrm{KCl}-$ extracts of the organic layers and the mineral soil horizons twice in $2004.10 \mathrm{~g}$ of mineral soil or $5 \mathrm{~g}$ of organic layer material were suspended in $100 \mathrm{ml} 0.1 \mathrm{M} \mathrm{KCl}$ solution and shaken for two hours $(180 \mathrm{rpm})$. The concentrations of nitrate and 
1 ammonium $\mathrm{N}$ were determined photometrically with a continuous flow autoanalyzer

2 (Skalar Analytik GmbH, Germany). Nitrite was not considered separately but was

3 included in the nitrate fraction.

4

\section{$5 \quad$ Statistical analyses}

6 Most of the aggregate data presented in this study refer to stand level data of $\mathrm{C}$ pools

7 and fluxes in a single forest stand per elevation. To cope with the problem of lacking

8 repetition on the stand level, we additionally conducted a meta-analysis of altitudinal

9 transect studies in tropical forests and analysed this data set in a similar way as the

10 Ecuadorian transect data. Linear and simple non-linear regression analyses were applied

11 to identify significant effects of elevation, mean air temperature, annual precipitation,

12 soil moisture, proton concentration of the mineral soil, and $\mathrm{C} / \mathrm{N}$ ratio of the organic

13 layers on various biomass and production fractions. Additional regression analyses were

14 performed to search for significant correlations of these environmental factors with

15 elevation. All calculations were done using Xact software (SciLab, Hamburg, Germany,

16 version 8.0). For certain biomass and production fractions, differences between the five

17 stands were analysed with a non-parametric analysis of variance (Kruskal-Wallis test)

18 and a subsequent Mann-Whitney two-sample test (U-test) using the package SAS,

19 version 8.2 (SAS Institute, Cary, NC, USA).

20

21

\section{RESULTS}

\section{Altitudinal trends in tree biomass and productivity}

Total above- and belowground tree biomass decreased from 317 to $174 \mathrm{Mg}$ dry mass $\mathrm{ha}^{-1}$ (or 154 to $87 \mathrm{Mg} \mathrm{C}^{-1}$ ) between 1050 and $3060 \mathrm{~m}$ elevation, showing the minimum at $2380 \mathrm{~m}$ a.s.l., where stem density was markedly smaller than in the uppermost stand while mean tree height was relatively low. Aboveground live biomass (AGB) decreased to about $60 \%$ of its value at $1050 \mathrm{~m}$ between 1050 and $1890 \mathrm{~m}$ elevation and showed a further reduction to $40 \%$ in the uppermost stand at $3060 \mathrm{~m}$ (Table 2). The stand total of tree leaf biomass increased with elevation in the lower part of the transect from $6.8(1050 \mathrm{~m})$ to $9.7 \mathrm{Mg} \mathrm{ha}^{-1}(1890 \mathrm{~m})$, but showed a sharp decrease higher upslope to $3.6 \mathrm{Mg} \mathrm{ha}^{-1}$ at $3060 \mathrm{~m}$. In contrast to $\mathrm{AGB}$, belowground tree biomass (BGB) nearly doubled between 1050 and $3060 \mathrm{~m}$ (32 to $63 \mathrm{Mg} \mathrm{ha}^{-1}$ ), being more or less 
1 invariant between 1050 and $2380 \mathrm{~m}$ and showing a large increase toward the uppermost 2 stand at $3060 \mathrm{~m}$. While coarse and large root biomass (all roots $>2 \mathrm{~mm}$ in diameter) 3 remained constant between 1050 and $2380 \mathrm{~m}$ and increased only higher upslope, fine 4 root biomass $(\mathrm{d}<2 \mathrm{~mm})$ showed a more or less continuous increase from $2.7 \mathrm{Mg} \mathrm{ha}^{-1}$ 5 (1050 m) to $10.8 \mathrm{Mg} \mathrm{ha}^{-1}$ (3060 m). The proportion of leaf biomass in total biomass 6 remained unchanged between 1050 and $3060 \mathrm{~m}$ (2\%), while fine root biomass 7 contributed by less than $1 \%$ at $1050 \mathrm{~m}$ and increased to about $6 \%$ at $3060 \mathrm{~m}$. Total root 8 biomass (fine and coarse) accounted for roughly $10 \%$ of total biomass at $1050 \mathrm{~m}$ 9 (equivalent to a root/shoot biomass ratio of only 0.11 ), while roots contributed by about $1035 \%$ to total biomass at $3060 \mathrm{~m}$, yielding a $\mathrm{R} / \mathrm{S}$ ratio $>0.5$.

11 The production of leaf biomass was by far the most important single component of 12 aboveground productivity (ANPP) in all five forest stands, contributing by 50 to $65 \%$ to 13 ANPP. Only 5 to $25 \%$ of ANPP referred to wood growth which reached annual rates of 142.8 to $0.1 \mathrm{Mg}$ dry mass $\mathrm{ha}^{-1} \mathrm{yr}^{-1}$ or 1.4 to $<0.1 \mathrm{Mg} \mathrm{C}^{-1} \mathrm{yr}^{-1}$ in the stands (Table 2). 15 Wood increment showed a steeper elevational decrease from 1050 to $3060 \mathrm{~m}$ (to about $165 \%$ of the value at $1050 \mathrm{~m}$ ) than leaf production (reduction to about $35 \%$ ). Moreover, 17 broken and abscised twigs and non-tree litter components (such as fallen epiphytes) 18 represented a larger carbon sink in the two uppermost stands (2380 and $3060 \mathrm{~m}$ ) than 19 stem wood production. While wood production showed a more or less continuous decrease from 1050 to $3060 \mathrm{~m}$, leaf production remained stable up to $1890 \mathrm{~m}$, but dropped markedly higher upslope between 1890 and $3060 \mathrm{~m}$.

Similar to root biomass, root productivity deviated in its vertical pattern from that of ANPP. Coarse and large root increment as estimated from dendrometer readings and root biomass excavations showed a substantial variation among the five stands but revealed no significant trend with elevation. However, the highest coarse root productivity was recorded in the stands at $3060 \mathrm{~m}$ and $1540 \mathrm{~m}$ elevation where the wind exposure is higher than in the other three stands. Fine root production $\left(\mathrm{P}_{\mathrm{FR}}\right)$ as estimated from minirhizotron observations and root coring data was roughly 10 times larger than coarse root production and showed a significant increase from $1050 \mathrm{~m}\left(2.3 \mathrm{Mg} \mathrm{ha}^{-1} \mathrm{yr}^{-1}\right)$ to $3060 \mathrm{~m}\left(9.4 \mathrm{Mg} \mathrm{ha}^{-1} \mathrm{yr}^{-1}\right)$. Adding coarse and fine root production data gave total 31 belowground productivity (BNPP) figures in the range of 2.5 to $4.0 \mathrm{Mg} \mathrm{ha}^{-1} \mathrm{yr}^{-1}$ for the stands \#1-4, but a much higher productivity ( $>10 \mathrm{Mg} \mathrm{ha}^{-1} \mathrm{yr}^{-1}$ ) for the uppermost stand. 
1 (4.4 $\mathrm{Mg} \mathrm{ha}^{-1} \mathrm{yr}^{-1}$, see Material and Methods section), BNPP was estimated at $5.3 \mathrm{Mg} \mathrm{ha}^{-}$

$2{ }^{1} \mathrm{yr}^{-1}$ in the uppermost stand which is still higher than at the four lower elevations.

3 Total NPP as the sum of ANPP and BNPP showed no trend over the 2000-m elevation 4 distance: for the stands at 1050, 1540, 1890 and $3060 \mathrm{~m}$, very similar figures (12.4 $5 \quad 13.1 \mathrm{Mg}$ dry mass $\mathrm{ha}^{-1} \mathrm{yr}^{-1}$ or $6.1-6.6 \mathrm{Mg} \mathrm{C} \mathrm{ha}^{-1} \mathrm{yr}^{-1}$ ) were calculated. A significantly 6 smaller NPP total was found only for stand \#4 at $2380 \mathrm{~m}\left(7.9 \mathrm{Mg}\right.$ dry mass $\left.\mathrm{ha}^{-1} \mathrm{yr}^{-1}\right)$ 7 and stand \#5 at $3060 \mathrm{~m}$, if the conservative $\mathrm{P}_{\mathrm{FR}}$ value is used $\left(8.2 \mathrm{Mg} \mathrm{ha}^{-1} \mathrm{yr}^{-1}\right)$. The 8 marked decrease in ANPP along the slope, which is mainly caused by a reduction in 9 wood and leaf production, was at least partly compensated by a higher fine and coarse 10 root production at higher elevations.

\section{Possible factors underlying the elevation effect on biomass and productivity}

With a few exceptions (leaf biomass, non-tree litter), all aboveground biomass and production components showed a significant negative correlation with elevation, while this relationship was positive for fine root biomass and fine root productivity, either in a linear or a non-linear way (Table 3). However, most of the investigated climatological and edaphic factors were tightly correlated among each other, except for precipitation with a close relation only to soil moisture, VPD and soil $\mathrm{C} / \mathrm{N}$ ratio (Table 4). The covariation among elevation, mean temperature, mean VPD and soil $\mathrm{C} / \mathrm{N}$ ratio was particularly strong. Consequently, the biomass and productivity components investigated showed a similarly close relation to soil $\mathrm{C} / \mathrm{N}$ ratio, temperature and VPD as to elevation. Moreover, most of the biomass and production parameters revealed an even tighter association with the $\mathrm{C} / \mathrm{N}$ ratio of the organic Oi horizon than to elevation or temperature. In contrast, the weakest correlation was detected between biomass or productivity and precipitation (Table 3 ).

\section{Stocks of soil organic carbon}

28 The carbon stocks in the organic layers ranged between $11 \mathrm{Mg} \mathrm{Cha}^{-1}$ at $1050 \mathrm{~m}$ and $2975 \mathrm{Mg} \mathrm{ha}^{-1}$ at $3060 \mathrm{~m}$ and reflected the general increase in organic layer depth with 30 increasing altitude (Table 1). In the $0-30 \mathrm{~cm}$ horizon of the mineral soil, the SOC pools 31 varied between 61 and $128 \mathrm{Mg} \mathrm{Cha}^{-1}$ with no significant elevational trend visible. The 
1 \#1) and $204 \mathrm{Mg} \mathrm{ha}^{-1}$ (stand \#5) with no trend between 1050 and $2380 \mathrm{~m}$ and a very high

2 value close to the alpine timberline at $3060 \mathrm{~m}$.

3

4

\section{Discussion}

\section{$6 \quad$ Elevational changes in biomass and soil carbon stocks}

7 Our study is the first to investigate synchronously all major aboveground and 8 belowground biomass and production components in a long altitudinal transect in 9 tropical mountain forests. Other transect studies in tropical mountains (Hawaii: Raich et 10 al. 1997; Sabah, Malaysia: Kitayama \& Aiba 2002; Puerto Rico: Weaver \& Murphy 11 1990, Wang et al. 2003; Sulawesi, Indonesia: Culmsee et al. 2010) were less complete, 12 in most cases focusing only on aboveground compartments and often covering shorter altitudinal distances. Root biomass was only investigated in the transects on Mt. Kinabalu in Sabah and recently in the Peruvian Andes (Girardin et al., in press). According to figure 2A, aboveground live biomass (AGB) tended to decrease with elevation in all cited longer tropical mountain transects. The decrease was, however, not always continuous with elevation, which may result from a marked tree species turnover along the slope (as in Ecuador) or due to inadequate sampling of the local topographic variability. Due to the large scatter in the biomass data of the seven transects, the pooled data of the meta-analysis showed no significant AGB decrease between 500 and $3000 \mathrm{~m}$ a.s.l.

One striking result of the Ecuador transect study is the more than fourfold increase in standing fine root biomass from 1050 to $3060 \mathrm{~m}$ elevation. The few existing data on root biomass in tropical mountain forests also indicate that fine root biomass does increase, and not decrease, with elevation, which contrasts with the altitudinal patterns found for AGB (Leuschner et al. 2007). A positive altitudinal trend in root biomass was also reported from the transect studies by Kitayama \& Aiba (2002) on the slopes of Mt. Kinabalu and by Girardin et al. (2010, in press) in the Peruvian Andes. A compilation of literature data of root biomass in tropical forest stands at different altitudes also supports this finding (Hertel \& Leuschner 2010).

The Ecuadorian transect is also the first to provide detailed information on altitudinal trends in coarse and large root biomass, and total root biomass. Clearly, our coarse root data are doubtlessly underestimated in particular in the case of the lowermost stands 
1 where stem densities are lower, because the data base on excavations in soil pits at a 2 minimum stem distance of $1 \mathrm{~m}$. We expect that the coarse and large root biomass 3 directly under the stems is greater than at larger stem distance. Consequently, the stand 4 averages of coarse and large root biomass should be higher than measured, particularly 5 in the stands \# 1-3. Our data and those of Soethe et al. (2006a, b) indicate that trees 6 develop greater amounts of coarse and large root biomass at sites with elevated wind 7 exposure, where a good anchorage is important.

8 The carbon stocks in live tree biomass (above- and belowground) decreased from 154 9 (1050 m) to $87 \mathrm{Mg} \mathrm{Cha}^{-1}(3060 \mathrm{~m})$ in the Ecuadorian transect, while the total $\mathrm{C}$ pool $(\mathrm{C}$ 10 stocks in biomass and soil) showed no significant elevational trend (range: 188 - 291 $11 \mathrm{Mg} \mathrm{C} \mathrm{ha}{ }^{-1}$ ). Remarkably, the largest ecosystem C pool was detected in the uppermost 12 stand $(3060 \mathrm{~m})$ close to the alpine tree line. Given that Amazonian lowland forests store 13 on average about $210 \mathrm{Mg} \mathrm{C} \mathrm{ha}^{-1}$ in biomass (above- and belowground, Malhi et al. 14 2006) and $98 \mathrm{Mg} \mathrm{Cha}^{-1}$ in the soil (0-1 m, Batjes \& Dijkshoorn 1999), our data indicate 15 that neotropical high-elevation forests can also contain substantial amounts of $\mathrm{C}$ in 16 biomass and soil despite a relatively small tree size. Inventories in other tropical 17 mountain forests are needed to confirm this assumption.

\section{Elevational change in primary production}

20 Our study provides data not only on fine, coarse and large root biomass, but also on root productivity using up-to-date approaches of fine root growth measurement. Thus, we were able to analyze changes in total NPP (above- and belowground) with elevation, instead of focusing on aboveground productivity only, which must lead to wrong conclusions.

25 Stem wood increment showed a continuous and steep decline with elevation in this transect which exceeded the reduction in annual leaf biomass production and canopy fine litter fall. The data of seven other transect studies in the meta-analysis support these 28 altitudinal trends in stem wood and leaf production (Fig. 2B and 2C). While the absolute 29 ANPP figures for a certain elevation differed more than fivefold among the sites due to 30 floristic, climatic and edaphic differences between the study regions, leaf production 31 was much less variable across this pan-tropical data set. Carbon allocation to leaves must be a $\mathrm{C}$ sink of higher priority than stem wood growth in tropical mountain trees, because it is needed to maintain a sufficiently large leaf area. 
The elevational decrease in ANPP components contrasts with belowground

2 productivity which may consume similar or larger amounts of carbohydrates than wood

3 production in the Ecuadorian transect. At least in the two uppermost stands, a neglect of

4 root production would have led to unrealistic conclusions on the productivity of the

5 forests. When considering only the four stands between 1050 and $2380 \mathrm{~m}$, we found

6 based on the minirhizotron approach a significant increase in $\mathrm{P}_{\mathrm{FR}}$ with elevation (from

72.3 to $\left.3.7 \mathrm{Mg} \mathrm{ha}^{-1} \mathrm{yr}^{-1}\right)$. By including the much higher production value for the 8 uppermost stand at $3060 \mathrm{~m}\left(9.4 \mathrm{Mg} \mathrm{ha}^{-1} \mathrm{yr}^{-1}\right)$, even an exponential increase in $\mathrm{P}_{\mathrm{FR}}$ with 9 altitude appears. For several reasons, however, we assumed that the figure of $9.4 \mathrm{Mg} \mathrm{ha}^{-}$ $10{ }^{1} \mathrm{yr}^{-1}$ for the uppermost stand represents an overestimation of root productivity and we 11 consequently used a more conservative $\mathrm{P}_{\mathrm{FR}}$ value for this stand by extrapolating the 12 linear trend of the four lowermost stands to $3060 \mathrm{~m}$ (see Material and Methods section). 13 This reduced fine root production estimate for the uppermost stand (4.4 $\mathrm{Mg} \mathrm{ha}^{-1} \mathrm{yr}^{-1}$ ) 14 appears much more plausible than the original high value, given that canopy carbon gain decreases by at least 50\% from 1050 to $3060 \mathrm{~m}$ (Moser et al. 2007).

Along the transect, fine root production correlated positively with elevation and with variables indicating poor nutrient availability (i.e. high soil acidity, high $\mathrm{C} / \mathrm{N}$ ratio and high soil moisture). These factors are known to reduce fine root longevity (Eissenstat \& 19 Yanai 1997; Eissenstat et al. 2000) and thus could have increased fine root mortality in the soils at high elevations, thereby promoting fine root growth for compensating the root mass loss. Further, there is the possibility that fine root growth is stimulated in the high-elevation soils by the lowered mass-specific mineralization rates which reduce the $\mathrm{N}$ (and P) supply rates per soil volume, but which could promote the exploration of additional soil patches by root extension growth. Nutrient addition experiments are needed to clarify what factors are responsible for the high values of fine root biomass and productivity in the Ecuadorian upper montane forests.

Adding the aboveground and belowground production figures allows to estimate stand net primary production (NPP) and the related sequestration of carbon. NPP as the difference between canopy carbon gain and total plant respiration was approximated here by adding all biomass increment terms that were measured in the study. Based on the most likely estimate of fine root production, our data indicate only minor or no 
1 productivity decrease from 1890 to $3060 \mathrm{~m}$ (to about $8.2 \mathrm{Mg} \mathrm{ha}^{-1} \mathrm{yr}^{-1}$ ), yielding a

2 reduction in NPP by about $40 \%$ between 1050 and $3060 \mathrm{~m}$.

3 Despite great efforts to measure above- and belowground biomass and production as 4 precisely as possible, we were not able to quantify all relevant plant-related carbon 5 sinks. In particular, we ignored processes such as above- and belowground herbivory, 6 rhizodeposition, C transfer to mycorrhizal hyphae, and emission of volatile organic 7 compounds that, in most cases, have not yet been quantified in tropical forests (Clark et 8 al. 2001a, b).

\section{Is tree growth limited by C sink or C source strength at high elevations?}

11 A more or less continuous decrease of tree height with elevation is perhaps the most obvious structural change occurring in our 2000-m altitudinal transect. In many other mountain forests, tropical and temperate, tree size tends to decrease with altitude more or less continuously, and not abruptly, toward the alpine tree line (Liebermann et al. 1996; Raich et al. 1997; Aiba \& Kitayama 1999; Pollmann \& Hildebrand 2005; Shi et al. 2008). This indicates that wood production is increasingly limited by environmental constraints or assimilate shortage when approaching the uppermost limit of tree growth.

18 Bruijnzeel \& Veneklaas (1998) proposed various environmental factors that could be 19 responsible for a growth reduction of tropical trees at higher elevations, among them (1) 20 reduced leaf temperatures and their effects on carbon gain, (2) periodic water shortage, (3) temporal soil hypoxia resulting in reduced root activity, (4) nutrient shortage and/or 22 nutrient uptake limitation, (5) high concentrations of phenolic substances in the soil, (6) 23 high doses of UV-b radiation, and (7) exposure to strong winds. In the following, we focus on factors directly or indirectly related to the acquisition and investment of carbon for tree growth.

26 The NPP decrease along mountain slopes, as observed in this study, could have different reasons: (i) a reduction in $\mathrm{C}$ source strength, i.e. decreased canopy carbon gain 28 at higher elevations, (ii) increased $\mathrm{C}$ consumption by plant respiration, and (iii) reduced 29 C sink strength, i.e. environmentally-induced reductions in tree growth at higher 30 elevations despite sufficient carbohydrate supply. Canopy carbon gain undoubtedly 31 decreases markedly with elevation in this transect, simply because the LAI at $3060 \mathrm{~m}$ reaches only $40 \%$ of the stand leaf area at $1050 \mathrm{~m}$. We estimate that the annual canopy assimilation must decline by at least $50 \%$ between 1050 and $3060 \mathrm{~m}$ because light- 
1 saturated net photosynthesis rate (leaf-area basis) does not change significantly along

2 the 2000-m elevation distance (B. Wittig, pers. comm.).

3 Forest NPP could also decrease with elevation if plant respiration losses (relative to $\mathrm{C}$ 4 gain) were increasing with elevation. This possibility can definitely be excluded. A 5 rough extrapolation of stem wood and soil (and root) respiration measurements to the 6 stand level indicates that wood respiration must have decreased at least to a quarter of 7 its rate at $1050 \mathrm{~m}$ (Zach et al. 2008). Soil (and included root) respiration declined even 8 more rapidly than wood respiration (Iost et. al. 2008), leaving relatively more of the 9 assimilated carbohydrates for NPP at $3060 \mathrm{~m}$ than at $1050 \mathrm{~m}$.

10 Whether sink limitation of growth, i.e. reduced meristematic activity of high-elevation 11 trees, is responsible for the reduction in NPP, may ultimately be decided only on the 12 basis of physiological studies in the laboratory. Indirect evidence from the Ecuador 13 transect seems to indicate that stem wood cambial activity is reduced with elevation 14 independently of carbohydrate supply because stem wood increment decreased much more rapidly between 1050 and $3060 \mathrm{~m}$ (to $5 \%$ of its value at $1050 \mathrm{~m}$ ) than did the leaf area index as an estimator of canopy carbon gain (to about 35\%). However, we also observed a marked increase, perhaps a doubling, of fine root production from 1050 to meristematic activity is reduced from low to high elevation due to the temperature reduction from 19 to $9{ }^{\circ} \mathrm{C}$. The minirhizotron observations showed that the fine roots grew indeed more slowly at higher elevation, but turned over as rapidly as at $1050 \mathrm{~m}$ due to a reduced longevity (see Table 5). More important, the fine root system of the stand at $3060 \mathrm{~m}$ was four times larger than that at $1050 \mathrm{~m}$, resulting in a larger $\mathrm{C}$ sink strength at higher than at lower elevations (Graefe et al. 2008b). It is not very likely that stem wood growth is reduced due to environmental limitation of meristematic activity but fine root growth of the same tree is not.

We conclude that the reduction in NPP by roughly $40 \%$ between 1050 and $3060 \mathrm{~m}$ cannot primarily be attributed to a $\mathrm{C}$ sink limitation of tree growth. A much more plausible explanation is that $\mathrm{C}$ source limitation is the predominant cause, i.e. an elevational decrease in canopy carbon gain, which increasingly limits tree growth towards higher elevation, though at different intensities in the aboveground and belowground tree compartments. It is striking that estimated canopy C gain and NPP seem to decrease at roughly similar rates between 1050 and $3060 \mathrm{~m}$ (by about 40 and > 
$150 \%$, respectively). Nevertheless, co-limitation of tree growth by reduced C source 2 strength cannot be excluded.

3 Increasing $\mathrm{C}$ source limitation at higher elevation in the Ecuadorian mountain forests 4 is mostly a consequence of a reduction in leaf area, and not of reduced photosynthetic 5 activity. From foliar nutrient concentrations and soil chemical data, we conclude that a 6 combined effect of increasing $\mathrm{N}$ limitation and decreasing temperatures with increasing 7 elevation must primarily be responsible for this marked leaf area reduction. A large 8 reduction in the mass-specific gross $\mathrm{N}$ mineralization rate in the organic topsoil 9 measured by the ${ }^{15} \mathrm{~N}$ pool dilution approach was found to be associated with a marked 10 increase in the $\mathrm{C} / \mathrm{N}$ ratio (from 22 to $63 \mathrm{~g} \mathrm{~g}^{-1}$ ) of the organic top layer, and a 20-fold 11 decrease in the concentration of $\mathrm{KCl}$-extractable inorganic $\mathrm{N}$ between 1050 and $3060 \mathrm{~m}$ 12 (Iost 2007). While $\mathrm{N}$ availability decreased markedly with elevation on a soil mass 13 basis, a much slighter decrease, or perhaps no change, was detected when $\mathrm{N}$ 14 mineralization was related to ground area because the depth of the organic layers increased. Thus, the root systems of the high-elevation forests face a greatly reduced $\mathrm{N}$ supply density ( $\mathrm{N}$ release per soil volume) which may require the build-up of a more extended and costly root system to maintain nutrient uptake. This could explain the extraordinarily high amount of fine root biomass in these soils.

19 Nitrogen limitation of tree growth in general, and of leaf growth in particular, is 20 further indicated by a considerable decrease of foliar N concentrations and SLA in upslope direction, and a concomitant increase in leaf longevity toward the uppermost stand (see Table 5). Smaller and thicker leaves with lower $\mathrm{N}$ concentration are a typical attribute of tropical trees at high elevations (Grubb \& Tanner 1976, Grubb 1977). Besides $\mathrm{N}$ shortage, harsh environments with cold nights and high radiation intensities, as they occur in high-altitude environments, may also be the cause of leaves with high $\mathrm{C} / \mathrm{N}$ ratios and low SLA. However, extreme climatic factors as a cause of the formation of durable, carbon-rich tree leaves could not explain why the trees at high elevations in 28 Ecuador reduce their stand leaf area, instead of forming a larger number of smaller 29 leaves adapted to the harsh environment, thereby compensating for the reduction in 30 individual leaf size. Moreover, the $\mathrm{N}$ pool in stand leaf biomass decreased to about $33 \%$ 31 between 1050 and $3060 \mathrm{~m}$ in this transect (see Table 5) indicating that the formation of 
1 toward higher elevations. This is support for the assumption that $\mathrm{N}$ limitation is the 2 primary cause of the marked leaf area and NPP reduction with elevation in this transect.

3 Increasing $\mathrm{N}$ limitation with elevation should also be the cause of the tremendous $\mathrm{C}$ 4 allocation shift from above- to belowground organs observed in our transect. Following 5 the resource balance hypothesis formulated by Bloom et al. (1985), this shift is best 6 explained by a growing importance of limiting soil resources with increasing elevation.

7 Increasing $\mathrm{C}$ and nutrient allocation to roots may represent a compensatory measure of

8 the trees to cope with increasing growth limitation by nutrient shortage with elevation,

9 and in the case of the coarse and large root system, by the growing need for stable 10 anchorage due to high wind loads. Interestingly, Duivenvoorden and Lips (1995) 11 observed a similarly large shift of $\mathrm{C}$ allocation to roots in Amazonian lowland forests as nutrient availability decreased. Girardin et al. (2010, in press) reported a more than threefold increase in fine root biomass between 200 and 3000 m elevation in a Peruvian altitudinal transect. In contrast, they observed a decrease, and not an increase, in fine root production with elevation. Additional transect studies investigating the $\mathrm{C}$ balance of tropical mountain forests are needed to draw more general conclusions on altitudinal trends in belowground productivity.

18 Yet, we cannot rule out that other factors such as increasing soil moisture and more 19 frequent soil hypoxia are also contributing to the observed reduction in LAI and the increase in R/S ratio with elevation, since LAI and R/S showed a close relation to those factors as well. Multi-factorial growth experiments with tropical trees are needed to disentangle the physiological effects of those environmental factors that change in

We conclude that carbon budgets of tropical mountain forests, that ignore root biomass and root productivity, will lead to wrong conclusions on the size and altitudinal change of $\mathrm{C}$ storage and $\mathrm{C}$ sequestration in these ecosystems. High-elevation forests in south Ecuador contain relatively large $\mathrm{C}$ stocks in biomass and soil despite their low stunted stature, which is a consequence of large SOC pools and a high root biomass. Aboveground and belowground biomass and productivity show opposite altitudinal trends indicating a shift from predominant light to nutrient $(\mathrm{N})$ limitation of tree growth with increasing elevation. The large reduction in stand leaf area with elevation is most likely a consequence of a more pronounced $\mathrm{N}$ limitation at higher elevations. We 
1 propose that reductions in leaf area and associated canopy carbon gain caused by $\mathrm{N}$ 2 limitation, i.e. a $\mathrm{C}$ source limitation of tree growth, are more likely causes of the 3 reduction in aboveground tree size and biomass with altitude in south Ecuador than is $\mathrm{C}$ 4 sink limitation. Transect studies in other tropical mountains have to confirm whether 5 these results are of more general validity.

6

7

\section{ACKNOWLEDGEMENTS}

9 We thank Marina Röderstein, Jürgen Homeier, Bernhard Schuldt and Malte Unger, 10 University of Göttingen, for data on fine root biomass and root $\mathrm{C} / \mathrm{N}$ ratio in the 11 uppermost three stands, tree species composition, foliar $\mathrm{N}$ content and 12 photosynthetically active radiation and P. Emck \& M. Richter, University of Erlangen, 13 for precipitation data. We are grateful to the Fundación Científica San Francisco 14 (Nature and Culture International) for the permission to work in the RBSF and ECSF, to the Ministerio del Ambiente in Quito for research permits and to the Deutsche Forschungsgemeinschaft (DFG) for financial funding within the Research Unit 402. Comments by four anonymous reviewers greatly improved the manuscript.

\section{REFERENCES}

Aiba S, Kitayama K (1999) Structure, composition and species diversity in an altitudesubstrate matrix of rain forest tree communities on Mount Kinabalu, Borneo. Plant Ecology, 140, 139-157.

Balslev H, Øllgaard B (2002) Mapa de vegetación del sur de Ecuador. In: Botánica Austroecuatoriana - Estudios sobre los recursos vegetales en las provincias de el Oro, Loja y Zamora-Chinchipe (eds Aguirre ZM, Madsen JE, Cotton E, Balslev H), pp. 51-64. Ediciones ABYA YALA, Quito.

Baker TR, Phillips OL, Malhi Y et al. (2004) Increasing biomass in Amazonian forest plots. Philosophical Transaction of the Royal Society London B, 359, 353-365.

Batjes NH, Dijkshoorn JA (1999) Carbon and nitrogen stocks in the soils of the Amazon region. Geoderma, 89, 273-286.

Bloom AJ, Chapin III FS, Mooney HA (1985) Resource limitation in plants - an economic analogy. Annual Review of Ecology and Systematics, 16, 363-392. 
Brown S (1997) Estimating biomass and biomass change of tropical forests: a primer. FAO Forestry Paper, 134.

Bruijnzeel IA, Procter J (1995) Hydrology and biogeochemistry of tropical montane cloud forest: what do we really know? In: Tropical montane cloud forests (eds Lawrence HS, Juvrik JO, Scatena FN), pp. 38-78. Springer, New York, Ecological Studies, 110.

Bruijnzeel LA, Veneklaas EJ (1998) Climatic conditions and tropical montane forest productivity: the fog has not lifted yet. Ecology, 79, 3-9.

Chave J, Condit R, Aguilar S, Hernandez A, Lao S, Perez R (2004) Error propagation and scaling for tropical forest biomass estimates. Philosophical Transaction of the Royal Society London B, 359, 409-420.

Chave J, Andalo C, Brown S, et al. (2005) Tree allometry and improved estimation of carbon stocks and balance in tropical forests. Oecologia, 145, 87-99.

Clark DA (2007) Detecting tropical forests' responses to global climatic and atmospheric change: current challenges and a way forward. Biotropica, 39, 4-19.

Clark DA, Brown S, Kicklighter DW, Chambers JQ, Thomlinson JR, Ni J (2001a) Measuring net primary production in forests: concepts and field methods. Ecological Applications, 11, 356-370.

Clark DA, Brown S, Kicklighter DW, Chambers JQ, Thomlinson JR, Ni J, Holland EA (2001b) Net primary production in tropical forests: an evaluation and synthesis of existing field data. Ecological Applications, 11, 371-384.

Clark DA, Piper SC, Keeling CD, Clark DB (2003) Tropical rain forest tree growth and atmospheric carbon dynamics linked to interannual temperature variation during 1984-2000. Proceedings of the National Academy of Sciences of the United States of America, 100, 5852-5857.

Culmsee H, Leuschner Ch, Moser G, Pitopang R (2010) Forest aboveground biomass along an altitudinal transect in Sulawesi, Indonesia, and the role of extra-tropical Fagaceae. Journal of Biogeography, in press.

Dixon RK, Brown S, Houghton RA, Solomon AM, Trexler MC, Wiesniewsky J (1994) Carbon pool and flux of global forest ecosystems. Science, 263, 185-190.

Duivenvoorden JF, Lips JM (1995) A land-ecological study of soils, vegetation, and plant diversity in Colombian Amazonia. The Tropenbos Foundation. Wageningen. Tropenbos Series, 12, 1-437. 
1 Eissenstat DM (1992) Costs and benefits of constructing roots of small diameter. Journal of Plant Nutrition, 15, 763-782.

Eissenstat DM, Yanai RD (1997) The ecology of root lifespan. Advances in Ecological Research, 27, 1-60.

Eissenstat DM, Wells CE, Yanai RD, Whitbeck JL (2000) Building roots in a changing environment: implications for root longevity. New Phytologist, 147, 33-42.

Espeleta K-F, Clark DA (2007) Multi-scale variation in fine-root biomass in a tropical rain forest: a seven year study. Ecological Monographs, 77, 377-404.

FAO (2007) State of the Word's Forests. Rom.

Feeley KJ, Wright SJ, Nur Supardi MN, Kassim AR, Davies SJ (2007) Decelerating growth in tropical forest trees. Ecology Letters, 10, 461-469.

Finér L, Ohashi M, Noguchi K, Hirano Y (in press) Factors causing variation in fine root biomass in forest ecosystems. Forest Ecology and Management (in press).

Girardin CAJ, Malhi Y, Aragao LEOC, Mamani M, Huaraca W et al. (2010) Net primary production and its allocation along a tropical forest elevational transect in the Peruvian Andes. Global Change Biology.

Grace J, Meir P (2009) Tropical rain forests as old-growth forests. In: Old-Growth Forests. (eds Wirth C, Gleixner G, Heimann M), pp. 391-408. Springer, Berlin, Heidelberg. Ecological Studies, 207.

Grace J, Lloyd J, McIntyre J, Miranda A, Meir P, Miranda H, Nobre C, Moncrieff J, Massheder J, Malhi Y, Wright I, Gash J (1995) Carbon dioxide uptake by an undisturbed tropical rain forest in south-west Amazonia 1992-1993. Science, 270, 778-780.

Graefe S, Hertel D, Leuschner Ch (2008a) Fine root dynamics along a 2,000-m elevation transect in South Ecuadorian mountain forests. Plant and Soil, 231, 155166.

Graefe S, Hertel D, Leuschner Ch (2008b) Estimating fine root turnover in tropical forests along an elevational transect using minirhizotrons. Biotropica, 40, 536-542.

Grubb PJ (1977) Control of forest growth and distribution on wet tropical mountains with special reference to mineral nutrition. Annual Reviews of Ecology and Systematics, 8, 567-601.

Grubb PJ, Tanner EVJ (1976) The montane forests and soils of Jamaica: a reassessment. Journal of the Arnold Arboretum, 57, 33-68. 
1 Grubb PJ, Lloyd JR, Pennington TD, Whitmore TC (1963) A comparison of montane and lowland rain forest in Ecuador. I. The forest structure, physiognomy and floristics. Journal of Ecology, 51, 567-601.

Hendricks JJ, Hendrick RL, Wilson CA, Mitchell RJ, Pecot SD, Guo DL (2006) Assessing the patterns and controls of fine root dynamics: an empirical test and methodological review. Journal of Ecology, 94, 40-57.

Hertel D, Leuschner Ch (2010) Fine root mass and fine root production in tropical moist forests as dependent on soil, climate and elevation. In: Mountains in the mist: Science for conserving and managing tropical montane cloud forests (eds Bruijnzeel LA, Scatena, FH, Hamilton, LS), Cambridge University Press, in press.

Herbert DA, Fownes JH (1999) Forest productivity and efficiency of resource use across a chronosequence of tropical montane soils. Ecosystems, 2, 242-254.

Hölscher D, Köhler L, Kapelle M, Leuschner Ch (in press) Ecology and use of oldgrowth and recovering montane oak forest in the Cordillera de Talamanca, Costa Rica. In: Mountains in the mist: Science for conserving and managing tropical montane cloud forests (eds Bruijnzeel LA, Scatena, FH, Hamilton, LS), Cambridge University Press, in press.

Houghton RA, Lawrence KT, Hackler JL et al. (2001) The spatial distribution of forest biomass in the Brazilian Amazon. Global Change Biology, 7, 731-746.

Iost S (2007) Soil respiration, microbial respiration and mineralisation in soils of montane rainforests of Southern Ecuador: influence of altitude. $\mathrm{PhD}$ thesis, Technical University of Dresden, Germany, 171 pp. http://nbnresolving.de/urn:nbn:de:bsz:14-ds-1201126765623-42870

Iost S, Makeschin F, Abiy M, Haubrich F (2008) Biotic soil activity. In: Gradients in a tropical mountain ecosystem of Ecuador (eds Beck E, Bendix J, Kottke I, Makeschin F, Mosandl R), pp. 217-227. Springer, Berlin. Ecological Studies, 198.

Jackson RB, Canadell J, Ehleringer JR, Mooney HA, Sala OE, Schulze ED (1996) A global analysis of root distribution for terrestrial biomes. Oecologia, 108, 389-411.

Kitayama K, Aiba S-I (2002) Ecosystem structure and productivity of tropical rain forests along altitudinal gradients with contrasting soil phosphorus pools on Mount Kinabalu, Borneo. Journal of Ecology, 90, 37-51.

Körner C (2003) Carbon limitation in trees. Journal of Ecology, 91, 4-17. 
1 Körner C, Paulsen J (2004) A world-wide study of high altitude treeline temperatures. Journal of Biogeography, 31, 713-732.

Leuschner Ch, Hertel D, Coners H, Büttner V (2001) Root competition between beech and oak: a hypothesis. Oecologia, 126, 276-284.

Leuschner Ch, Moser G, Bertsch C, Röderstein M, Hertel D (2007) Large altitudinal increase in tree root/shoot ratio in tropical mountain forests of Ecuador. Basic and Applied Ecology, 8, 219-230.

Lieberman D, Lieberman M, Peralta R, Hartshorn GS (1996) Tropical forest structure and composition on a large-scale altitudinal gradient in Costa Rica. Journal of Ecology, 84, 137-152.

Litherland M, Aspden J, Jemielita R (1994) The metamorphic belts of Ecuador. No. 11 in Overseas Memoir of the British Geological Survey, Keyworth, U.K.

Da Costa ACL, Galbraith D, Almeida S, Portela BTT, da Costa M et al. (2010) Effect of $7 \mathrm{yr}$ of experimental drought on vegetation dynamics and biomass storage of an eastern Amazonian rainforest. New Phytologist, 187, 579-591.

Luyssaert S, Inglima I, Jungs M, Richardson AD, Reichstein M et al. (2007) $\mathrm{CO}_{2}$ balance of boreal, temperate, and tropical forests derived from a global database. Global Change Biology, 13, 2509-2537.

Mahli Y (2005) The carbon balance of the tropical forest biome. In: The carbon balance of forest biomes (eds Griffiths H, Jarvis PG), pp. 217-234. Tayler \& Francis, New York.

Malhi Y, Wood D, Baker TR, Wright J, Phillips OL, Cochrane T, Meir P, Chave J et al. (2006) The regional variation of aboveground live biomass in old-growth Amazonian forests. Global Change Biology, 12, 1107-1138.

Metcalfe D, Meir P, Williams M (2008) The effects of water availability on root growth and morphology in an Amazon rainforest. Plant and Soil, 311, 189-199.

Moser G, Hertel D, Leuschner Ch (2007) Altitudinal change in LAI and stand leaf biomass in tropical montane forests - a transect study in Ecuador and a pan-tropical meta-analysis. Ecosystems, 10, 924-935.

Moser G, Röderstein M, Soethe N, Hertel D, Leuschner Ch (2008) Altitudinal changes in stand structure and biomass allocation of tropical mountain forests in relation to microclimate and soil chemistry. In: Gradients in a Tropical Mountain Ecosystem 

of Ecuador (eds Beck E, Bendix J, Kottke I, Makeschin F, Mosandl R), pp. 229242. Springer, Berlin, Ecological Studies, 198.

3 Moser G, Leuschner Ch, Röderstein M, Graefe S, Soethe N, Hertel D (in press) Biomass and productivity of fine and coarse roots in five tropical mountain forests along an altitudinal transect in South Ecuador. Plant Ecology and Diversity.

Nadelhoffer KJ (2000) The potential effects of nitrogen deposition on fine-root production in forest ecosystems. New Phytologist, 147, 131-139.

Pollmann W, Hildebrand R (2005) Structure and the composition of species in timberline ecotones of the Southern Andes. In: Mountain ecosystems - studies in treeline ecology (eds Broll G, Keplin B) pp. 117-151. Springer, Berlin.

Raich JW, Russel AE, Vitousek PM (1997) Primary productivity and ecosystem development along an elevational gradient on Mauna Loa, Hawai'i. Ecology, 78, 707-721.

Richter M, Diertl K-H, Bussmann RW, Peters T (2008) Vegetation structures and ecological features of he upper tree line ecotone. In: Gradients in a Tropical Mountain Ecosystem of Ecuador (eds Beck E, Bendix J, Kottke I, Makeschin F, Mosandl R), pp. 229-242. Springer, Berlin, Ecological Studies, 198.

Schawe M, Glatzel S, Gerold G (2007) Soil development along an altitudinal transect in a Bolivian tropical montane rainforest: Podzolization vs. hydromorphy. Catena, 69, 83-90.

Shi P, Körner C, Hoch G (2008) A test of the growth-limitation theory for alpine tree line formation in evergreen and deciduous taxa of the eastern Himalayas. Functional Ecology, 22, 213-220.

Soepadmo E (1993) Tropical rain forests as carbon sinks. Chemosphere, 27, 1025-1039.

Soethe N, Lehmann J, Engels C (2006a). Root morphology and anchorage of six native tree species from a tropical montane forest and an elfin forest in Ecuador. Plant and Soil, 279, 173-185.

Soethe N, Lehmann J, Engels C (2006b). The vertical pattern of rooting and nutrient uptake at different altitudes of a south Ecuadorian montane forest. Plant and Soil, 286, 287-299.

Takyu M, Aiba S-I, Kitayama K (2003). Changes in biomass, productivity and decomposition along topographical gradients under different geological conditions 
1 in tropical lower montane forests on Mount Kinabalu, Borneo. Oecologia, 134, $2397-404$.

3 Tanner EVJ (1981) The decomposition of leaf litter in Jamaican montane rain forests. 4 Journal of Ecology, 69, 263-273.

5 Vogt KA, Vogt DJ, Palmiotto PA, Boon B, O'Hara J, Asbjornsen H (1996) Review of 6 root dynamics in forest ecosystems grouped by climate, climatic forest type and 7 species. Plant Soil, 187, 159-219.

8 Wang HQ, Hall CAS, Scatena FN, Fetcher N, Wu W (2003) Modelling the spatial and 9 temporal variability in climate and primary productivity across the Luquillo 10 Mountains, Puerto Rico. Forest Ecology and Management, 179, 69-94.

11 Weaver PL, Murphy PG (1990) Forest structure and productivity in Puerto-Rico 12 Luquillo Mountains. Biotropica, 22, 69-82.

13 Wilcke W, Hess T, Bengel C, Homeier J, Valarezo E, Zech W (2005) Coarse woody 14 debris in a montane forest in Ecuador: mass, $\mathrm{C}$ and nutrient stock, and turnover. in a tropical mountain rain forest in southern Ecuador. Tree Physiology, 28, 67-74. 
1 Table 1: Location and stand characteristics of the five study sites in South Ecuador:

2 Mean annual air temperature and relative air humidity were measured at $1.5 \mathrm{~m}$ height inside the stands,

3 soil moisture in $10 \mathrm{~cm}$ depth of the mineral soil; given are annual means, minimum and maximum (in

4 brackets) for the period April 2003 - March 2004; bedrock types after Litherland et al. 1994; soil

5 classification (FAO system), $\mathrm{pH}\left(\mathrm{CaCl}_{2}\right)$ of the mineral topsoil $(0-30 \mathrm{~cm}), \mathrm{C} / \mathrm{N}$ ratio of the organic layer

6 (L/Of1) and soil organic carbon (SOC; organic layers and 0-30 cm of mineral soil) after Iost (2007);

7 rainfall data are extrapolated from own measurements in a gap at approximately $1050 \mathrm{~m}$ (measuring

8 period Mai 2003 - Mai 2004), and from measurements in gaps at 1950, 2680 and $3170 \mathrm{~m}$ done by $\mathrm{P}$.

9 Emck \& M. Richter (3-year means, unpublished); data on forest structure, as mean diameter in breast

10 height (DBH), stem density, basal area and canopy height were measured for 80 trees per plot (Moser et

11 al. 2008); KCl-extractable inorganic N measured in April 2004 by Iost (2007, median and range), gross $\mathrm{N}$

12 mineralization according to ${ }^{15} \mathrm{~N}$ isotopic pool dilution approach (3 sites only), the pool of $\mathrm{KCl}$-extract. $\mathrm{N}$

13 in the org. layers is a rough estimate derived from $\mathrm{N}_{\text {inorg }}$ concentrations and humus mass; LAI derived

14 from annual leaf litter fall, specific leaf area (SLA) and leaf lifespan (Moser et al. 2007).

15

\begin{tabular}{|c|c|c|c|c|c|}
\hline Stand no. & 1 & 2 & 3 & 4 & 5 \\
\hline \multirow[t]{2}{*}{ Coordinates } & S $04^{\circ} 06^{\prime} 54^{\prime \prime}$ & S $04^{\circ 06} 42^{\prime \prime}$ & S $03^{\circ} 58^{\prime} 35^{\prime \prime}$ & S $03^{\circ} 59^{\prime} 19^{\prime \prime}$ & S $04^{\circ} 06^{\prime} 71^{\prime \prime}$ \\
\hline & W 78 ॰58'02”' & W 78 58'20”' & W 7904'65" & W 7904'55" & W 79¹0'58'" \\
\hline Elevation (m a.s.I.) & 1050 & 1540 & 1890 & 2380 & 3060 \\
\hline Inclination $\left({ }^{\circ}\right)$ & 26 & 10 & 31 & 28 & 27 \\
\hline Air temperature $\left({ }^{\circ} \mathrm{C}\right)$ & 19.4 & 17.5 & 15.7 & 13.2 & 9.4 \\
\hline$(\min -\max )$ & $(11.5-30.2)$ & $(11.2-26.7)$ & $(7.9-29.4)$ & $(7.0-25.1)$ & $(3.1-18.8)$ \\
\hline Rainfall (mm yr $\left.{ }^{-1}\right)$ & c. 2230 & c. 2300 & c. 1950 & c. 5000 & c. 4500 \\
\hline Relative air humidity (\%) & 88.7 & 88.9 & 90.8 & 93.3 & 93.5 \\
\hline$(\min -\max )$ & $(15.5-100)$ & $(31.7-100)$ & $(15.7-100)$ & $(34.0-100)$ & $(28.6-100)$ \\
\hline Bedrock types & $\begin{array}{l}\text { Leuco- and } \\
\text { hornblende, } \\
\text { granodiorites }\end{array}$ & $\begin{array}{l}\text { Leuco- and } \\
\text { hornblende, } \\
\text { granodiorites }\end{array}$ & $\begin{array}{l}\text { Black phyllites, } \\
\text { quartzite, } \\
\text { metasiltstone, } \\
\text { metasandstone }\end{array}$ & $\begin{array}{l}\text { Black phyllites, } \\
\text { quartzite, } \\
\text { metasiltstone, } \\
\text { metasandstone }\end{array}$ & $\begin{array}{l}\text { Black phyllites, } \\
\text { quartzite, } \\
\text { metasiltstone, } \\
\text { metasandstone }\end{array}$ \\
\hline Soil types & Alumic Acrisol & Alumic Acrisol & $\begin{array}{l}\text { Gleyic } \\
\text { Cambisol }\end{array}$ & $\begin{array}{l}\text { Gleyic } \\
\text { Cambisol }\end{array}$ & Podzol \\
\hline $\begin{array}{l}\text { Organic layer thickness } \\
\qquad(\mathrm{mm})\end{array}$ & 48 & 243 & 305 & 214 & 435 \\
\hline $\begin{array}{l}\text { Soil moisture (vol.\%) } \\
\qquad(\text { min-max) }\end{array}$ & $\begin{array}{l}29.7 \\
\qquad(15.3-38.5)\end{array}$ & $\begin{array}{l}30.3 \\
\quad(20.4-43.5)\end{array}$ & $\begin{array}{l}35.4 \\
\quad(27.4-44.7)\end{array}$ & $\begin{array}{l}44.7 \\
\qquad(35.7-48.7)\end{array}$ & $\begin{array}{l}49.1 \\
\qquad(39.5-59.5)\end{array}$ \\
\hline Soil pH $\left(\mathrm{CaCl}_{2}\right)$ & 3.94 & 3.90 & 3.52 & 3.26 & 2.86 \\
\hline SOC: organic layers & 11.1 & 50.5 & 36.5 & 47.8 & 75.1 \\
\hline
\end{tabular}




$$
\left(\mathrm{Mg} \mathrm{ha}^{-1}\right)
$$

$\mathrm{KCl}$-extract. inorganic $\mathrm{N}: \quad 45$

$0-10 \mathrm{~cm}$ min. soil

(43-69)

19

$\left(\mu \mathrm{g} \mathrm{g}^{-1}\right)$ (min-max)

Gross N mineralization: 159

(80-213)

Oi layer $\left(\mu \mathrm{g} \mathrm{g}^{-1} \mathrm{~d}^{-1}\right)$

(min-max)

Gross $\mathrm{N}$ mineralization: $0-10 \mathrm{~cm}$ min. soil $\left(\mu \mathrm{g} \mathrm{g}^{-1} \mathrm{~d}^{-1}\right)$ (min-max)

Pool of $\mathrm{KCl}$-extract. $\mathrm{N}_{\text {inorg }}$

2.9

2.5 in org. layers $\left(\mathrm{g} \mathrm{N} \mathrm{m}^{-2}\right)$

Mean DBH (cm)

Stem density ( $\mathrm{ha}^{-1}$ )

968

Basal area $\left(\mathrm{m}^{2} \mathrm{ha}^{-1}\right)$

33.6

Canopy height $(\mathrm{m})$

31.8

LAI $\left(\mathrm{m}^{2} \mathrm{~m}^{-2}\right)$

n.d.

6.0
61.2

73.6

128.4

$112( \pm 16)$

$160( \pm 17)$

$121( \pm 16)$

$204( \pm 27)$

28

234

(34-574)

46

17

(12-209)

63

6

(4-19)

73

(35-78)

26

38

(14-27)

(11-44)

(19-46)

115

n.d.

23

(107-120)

(0-32)

8

n.d.

13

(3-13)

(9-17)

3.3

3.1

1.1

\begin{tabular}{ll}
11.5 & 12.2 \\
2222 & 2333 \\
27.5 & 36.9 \\
21.7 & 18.9 \\
5.4 & 5.7 \\
\hline
\end{tabular}

$\begin{array}{ll}9.8 & 7.2 \\ 2753 & 8317 \\ 27.2 & 42.2 \\ 12.0 & 9.0 \\ 2.8 & 2.2\end{array}$


1 Table 2: Above- (AGB) and belowground biomass (BGB) and above- (ANPP) and

2 belowground production fractions (BNPP) of the five study plots.

$3{ }^{1}$ Data for the stands at 1890-3060 m after Leuschner et al. (2007), ${ }^{2}$ for the stand at $3060 \mathrm{~m}$ extrapolated

4 fine root production estimates are given in brackets.

5

\begin{tabular}{|c|c|c|c|c|c|c|c|c|c|c|}
\hline \multirow{3}{*}{$\begin{array}{l}\text { Stand no. } \\
\text { Elevation (m a.s.I.) }\end{array}$} & \multicolumn{5}{|c|}{ Dry mass } & \multicolumn{5}{|l|}{ Carbon } \\
\hline & 1 & 2 & 3 & 4 & 5 & 1 & 2 & 3 & 4 & 5 \\
\hline & 1050 & 1540 & 1890 & 2380 & 3060 & 1050 & 1540 & 1890 & 2380 & 3060 \\
\hline \multicolumn{11}{|l|}{ Biomass (Mg ha ${ }^{-1}$ ) } \\
\hline Tree leaves & 6.82 & 7.99 & 9.74 & 5.25 & 3.64 & 3.43 & 4.05 & 4.92 & 2.66 & 1.87 \\
\hline Stem wood & 278.25 & 159.50 & 163.21 & 94.57 & 108.56 & 134.67 & 77.35 & 79.15 & 45.11 & 51.67 \\
\hline Total AGB & 285.07 & 167.49 & 172.95 & 99.82 & 112.20 & 138.10 & 81.40 & 84.07 & 47.77 & 53.54 \\
\hline Coarse roots & 29.44 & 30.72 & 19.90 & 32.92 & 51.93 & 14.24 & 14.89 & 9.65 & 15.70 & 24.72 \\
\hline Fine roots ${ }^{1}$ & 2.66 & 5.62 & 6.18 & 6.29 & 10.84 & 1.23 & 2.66 & 2.81 & 3.03 & 5.42 \\
\hline Total BGB & 32.10 & 36.34 & 26.08 & 39.21 & 62.77 & 15.47 & 17.55 & 12.46 & 18.73 & 33.14 \\
\hline Total Tree Biomass & 317.17 & 203.83 & 199.03 & 145.03 & 174.97 & 153.57 & 98.95 & 96.53 & 66.50 & 86.68 \\
\hline \multicolumn{11}{|c|}{ Production $\left(\mathrm{Mg} \mathrm{ha}^{-1} \mathrm{yr}^{-1}\right)$} \\
\hline Tree leaves & 5.05 & 5.06 & 4.96 & 2.64 & 1.79 & 2.54 & 2.57 & 2.51 & 1.34 & 0.92 \\
\hline Reprod. organs & 0.91 & 0.43 & 0.36 & 0.11 & 0.07 & 0.45 & 0.21 & 0.18 & 0.05 & 0.03 \\
\hline Twigs & 1.13 & 0.93 & 0.88 & 0.39 & 0.39 & 0.55 & 0.45 & 0.43 & 0.19 & 0.19 \\
\hline Epiphytes & 0.28 & 0.58 & 0.25 & 0.25 & 0.21 & 0.14 & 0.29 & 0.13 & 0.13 & 0.11 \\
\hline Bamboo & 0.00 & 0.00 & 1.55 & 0.12 & 0.20 & 0.00 & 0.00 & 0.78 & 0.06 & 0.10 \\
\hline Other components & 0.41 & 0.34 & 0.34 & 0.14 & 0.04 & 0.21 & 0.17 & 0.17 & 0.07 & 0.02 \\
\hline Total fine litter & 7.78 & 7.34 & 8.34 & 3.65 & 2.70 & 3.89 & 3.69 & 4.20 & 1.84 & 1.37 \\
\hline $\begin{array}{l}\text { Stem wood incre- } \\
\text { ment }\end{array}$ & 2.82 & 1.58 & 0.87 & 0.22 & 0.14 & 1.37 & 0.77 & 0.42 & 0.11 & 0.07 \\
\hline Total ANPP & 10.60 & 8.92 & 9.21 & 3.87 & 2.84 & 5.26 & 4.46 & 4.62 & 1.95 & 1.44 \\
\hline Coarse roots & 0.17 & 0.79 & 0.23 & 0.23 & 0.89 & 0.08 & 0.38 & 0.11 & 0.11 & 0.42 \\
\hline Fine roots ${ }^{2}$ & 2.28 & 3.16 & 2.97 & 3.72 & $\begin{array}{r}9.40 \\
(4.42)\end{array}$ & 1.06 & 1.50 & 1.35 & 1.79 & $\begin{array}{r}4.70 \\
(2.21)\end{array}$ \\
\hline Total BNPP ${ }^{2}$ & 2.45 & 3.95 & 3.20 & 3.95 & $\begin{array}{l}10.29 \\
(5.31)\end{array}$ & 1.14 & 1.88 & 1.46 & 1.90 & $\begin{array}{r}5.12 \\
(2.66)\end{array}$ \\
\hline Total NPP ${ }^{2}$ & 13.05 & 12.84 & 12.41 & 7.85 & $\begin{array}{l}12.96 \\
(8.15)\end{array}$ & 6.40 & 6.34 & 6.08 & 3.85 & $\begin{array}{r}6.56 \\
(4.10)\end{array}$ \\
\hline
\end{tabular}


1 Table 3: Results of regression analyses relating various biomass and production fractions to elevation and six climatic and edaphic variables.

2 Elevation in $\mathrm{m}$ a.s.l., mean air temperature in ${ }^{\circ} \mathrm{C}$, vapour pressure deficit VPD in $\mathrm{hPa}$, annual precipitation in mm $\mathrm{yr}^{-1}$, soil moisture in vol.\%, proton concentration of

3 mineral soil derived from $\mathrm{pH}$ value, $\mathrm{C} / \mathrm{N}$ ratio of the organic Oi layer. Significant relations are printed in bold ( $\mathrm{p}=0.05$ ), negative relationships are indicated by - , non-

4 linear relationships are marked with *. ${ }^{1}$ Regression analyses were calculated considering the extrapolated fine root production value for the $3060 \mathrm{~m}$ stand 5

\begin{tabular}{|c|c|c|c|c|c|c|c|c|c|c|c|c|c|c|}
\hline \multirow[b]{2}{*}{ Dependent } & \multicolumn{2}{|c|}{ Elevation } & \multicolumn{2}{|c|}{ Temperature } & \multicolumn{2}{|l|}{ VPD } & \multicolumn{2}{|c|}{ Precipitation } & \multicolumn{2}{|c|}{ Soil moisture } & \multicolumn{2}{|c|}{$\begin{array}{l}\text { Proton } \\
\text { concentration }\end{array}$} & \multicolumn{2}{|c|}{$\mathrm{C} / \mathrm{N}$ ratio } \\
\hline & $r_{\text {adj }}^{2}$ & $\mathrm{p}$ & $r_{\text {adj }}^{2}$ & $p$ & $r_{\text {adj }}^{2}$ & $\mathrm{p}$ & $r^{2}{ }_{a d j}$ & $\mathrm{p}$ & $r^{2}{ }_{a d j}$ & $p$ & $r^{2}{ }_{a d j}$ & $p$ & $r^{2}{ }_{a d j}$ & $\mathrm{p}$ \\
\hline \multicolumn{15}{|l|}{ Biomass } \\
\hline Leaves & - 0.25 & 0.112 & 0.31 & 0.096 & 0.31 & 0.097 & 0.65 & 0.031 & - 0.44 & 0.068 & - 0.49 & 0.058 & - 0.59 & 0.040 \\
\hline AG wood & -0.81 & $0.045 *$ & 0.86 & $0.032 *$ & 0.61 & 0.037 & 0.38 & 0.081 & -0.50 & 0.055 & - 0.18 & 0.133 & -0.98 & 0.003 \\
\hline AGB & -0.85 & 0.036 * & 0.82 & $0.034 *$ & 0.63 & 0.033 & 0.41 & 0.073 & -0.53 & 0.050 & -0.21 & 0.124 & -0.99 & 0.002 \\
\hline Coarse roots & 0.13 & 0.149 & -0.18 & 0.131 & -0.01 & 0.191 & 0.14 & 0.145 & 0.12 & 0.153 & 0.48 & 0.059 & 0.46 & 0.064 \\
\hline Fine roots & 0.87 & 0.006 & -0.86 & 0.007 & -0.63 & 0.033 & 0.16 & 0.140 & 0.61 & 0.036 & 0.80 & 0.012 & 0.77 & 0.015 \\
\hline BGB & 0.58 & 0.040 & -0.64 & 0.032 & -0.83 & 0.041 & 0.57 & 0.043 & 0.82 & 0.043 & 0.78 & 0.014 & 0.87 & 0.006 \\
\hline Total biomass & -0.88 & $0.025 *$ & 0.88 & $0.027 *$ & 0.69 & 0.080 & -0.24 & 0.114 & $\begin{array}{l}-\quad 0.36 \\
\end{array}$ & 0.085 & -0.83 & $0.040 *$ & -0.93 & 0.014 \\
\hline \multicolumn{15}{|l|}{ Production } \\
\hline Leaves & -0.79 & 0.013 & 0.83 & 0.009 & 0.87 & 0.006 & 0.85 & 0.007 & 0.93 & 0.002 & 0.77 & 0.015 & 0.93 & 0.002 \\
\hline $\begin{array}{l}\text { Reproductive } \\
\text { organs }\end{array}$ & -0.97 & 0.006 & 0.95 & 0.009 & 0.82 & 0.043 & 0.39 & 0.078 & 0.60 & 0.108 & 0.55 & 0.119 & 0.97 & 0.006 \\
\hline Twigs & -0.84 & 0.008 & 0.82 & 0.010 & 0.93 & 0.002 & 0.84 & 0.009 & 0.91 & 0.003 & 0.54 & 0.048 & 0.93 & 0.015 \\
\hline Wood & -0.98 & $0.003 *$ & 0.99 & 0.002 & 0.95 & 0.009 & 0.37 & 0.081 & 0.80 & 0.049 & 0.08 & 0.060 * & 0.85 & 0.035 \\
\hline Tree ANPP & -0.93 & 0.002 & 0.92 & 0.003 & 0.97 & 0.001 & 0.74 & 0.019 & 0.95 & 0.001 & 0.87 & $0.030 *$ & 0.95 & 0.009 \\
\hline Non-tree litter & $-\quad-0.19$ & 0.293 & -0.15 & 0.272 & -0.16 & 0.276 & 0.30 & 0.100 & -0.08 & 0.230 & -0.02 & 0.206 & 0.10 & 0.158 \\
\hline Total ANPP & -0.85 & 0.007 & 0.86 & 0.007 & 0.90 & 0.004 & 0.86 & 0.007 & 0.92 & 0.003 & 0.69 & 0.026 & 0.92 & 0.003 \\
\hline
\end{tabular}




\begin{tabular}{|c|c|c|c|c|c|c|c|c|c|c|c|c|c|c|c|c|c|c|c|c|}
\hline Coarse roots & & 0.07 & 0.168 & & 0.07 & 0.168 & & -0.16 & 0.274 & & -0.24 & 0.331 & & -0.14 & 0.236 & 0.19 & 0.129 & & 0.18 & 0.132 \\
\hline Fine roots ${ }^{1}$ & & 0.92 & 0.003 & - & 0.90 & 0.004 & - & 0.79 & 0.013 & & 0.54 & 0.049 & & 0.78 & 0.014 & 0.73 & 0.019 & & 0.91 & 0.003 \\
\hline Total BNPP ${ }^{1}$ & & 0.74 & 0.018 & - & 0.73 & 0.020 & - & 0.51 & 0.052 & & 0.30 & 0.099 & & 0.52 & 0.052 & 0.65 & 0.030 & & 0.79 & 0.013 \\
\hline Total NPP ${ }^{1}$ & - & 0.71 & 0.023 & & 0.72 & 0.021 & & 0.87 & 0.006 & - & 0.95 & 0.001 & - & 0.90 & 0.004 & 0.52 & 0.514 & - & 0.77 & 0.15 \\
\hline LAI & - & 0.80 & 0.013 & & 0.81 & 0.011 & & 0.86 & 0.007 & - & 0.90 & 0.004 & - & 0.90 & 0.004 & -0.68 & 0.026 & - & 0.91 & 0.003 \\
\hline BNPP/ANPP ${ }^{1}$ & & 0.86 & 0.007 & - & 0.90 & 0.004 & - & 0.98 & 0.004 & & 0.55 & 0.047 & & 0.98 & 0.004 & 0.96 & 0.001 & & 0.98 & $<0.001$ \\
\hline $\begin{array}{l}\mathrm{N} \text { pool in leaf } \\
\text { biomass }\end{array}$ & - & 0.54 & 0.048 & & 0.58 & 0.041 & & 0.64 & 0.032 & - & 0.92 & 0.002 & - & 0.73 & 0.020 & 0.56 & 0.045 & - & 0.79 & 0.014 \\
\hline
\end{tabular}


1 Table 4: Results of correlation analyses between six environmental variables and elevation in the five Ecuadorian

2 study plots (Pearson correlation coefficient $\mathrm{r}$ and $\mathrm{p}$ ).

3 Elevation in m a.s.l., mean air temperature in ${ }^{\circ} \mathrm{C}$, VPD in $\mathrm{hPa}$, annual precipitation in $\mathrm{mm}^{-1} \mathrm{r}^{-1}$, soil moisture in vol.\%, proton

4 concentration $(\mathrm{pH})$ of the upper mineral soil in $\mathrm{mol} \mathrm{L}^{-1}, \mathrm{C} / \mathrm{N}$ ratio of the organic Oi layer in $\mathrm{g} \mathrm{g}^{-1}$. Significant relationships are printed

$5 \quad$ in bold $(\mathrm{p}<0.05)$, negative relationships are indicated by - .

6

\begin{tabular}{|c|c|c|c|c|c|c|c|c|c|c|c|c|}
\hline & \multicolumn{2}{|c|}{ Elevation } & \multicolumn{2}{|c|}{ Temperature } & \multicolumn{2}{|l|}{ VPD } & \multicolumn{2}{|c|}{ Precipitation } & \multicolumn{2}{|c|}{ Soil moisture } & \multicolumn{2}{|c|}{$\begin{array}{l}\text { Proton } \\
\text { concentration }\end{array}$} \\
\hline & $r$ & $p$ & $r$ & $p$ & $r$ & $p$ & $r$ & $p$ & $r$ & $p$ & $r$ & $p$ \\
\hline Temperature & +1.00 & $<0.001$ & & & & & & w & & & & \\
\hline VPD & -0.97 & 0.002 & +0.97 & 0.002 & & & & & & & & \\
\hline Precipitation & +0.80 & 0.053 & - 0.80 & 0.051 & -0.88 & 0.025 & & & & & & \\
\hline Soil moisture & +0.97 & 0.003 & - 0.97 & 0.002 & -0.99 & $<0.001$ & +0.90 & 0.019 & & & & \\
\hline $\begin{array}{l}\text { Proton } \\
\text { concentration }\end{array}$ & +0.93 & 0.011 & - 0.95 & 0.006 & -0.88 & 0.023 & +0.72 & 0.083 & +0.91 & 0.015 & & \\
\hline $\mathrm{C} / \mathrm{N}$ ratio & +0.96 & 0.004 & - 0.97 & 0.002 & -0.94 & 0.008 & +0.86 & 0.030 & +0.96 & 0.005 & +0.96 & 0.004 \\
\hline
\end{tabular}


1 Table 5: Leaf and root traits, and various biomass and production ratios of the five forest stands.

2 AGB - aboveground biomass, ANPP - aboveground net primary production, BGB - belowground biomass,

3 BNPP - belowground net primary production, n.d. - no data; ${ }^{1}$ from Moser et al. (2007). ${ }^{2}$ from Graefe et al.

4 (2008b). ${ }^{3}$ for the stand at $3060 \mathrm{~m}$ : extrapolated fine root production estimate from the trend line of stands 1 -

54 in brackets.

6

\begin{tabular}{|c|c|c|c|c|c|}
\hline Stand no. & 1 & 2 & 3 & 4 & 5 \\
\hline Elevation (m a.s.I.) & 1050 & 1540 & 1890 & 2380 & 3060 \\
\hline \multicolumn{6}{|l|}{ Leaves } \\
\hline Mean leaf longevity (months) ${ }^{1}$ & 16.2 & 19.1 & 23.6 & 23.7 & 24.5 \\
\hline $\mathrm{N}$ pool in leaf biomass $\left(\mathrm{Mg} \mathrm{ha}^{-1}\right)$ & 0.21 & 0.21 & 0.25 & 0.09 & 0.07 \\
\hline Leaf $\mathrm{N}$ content / area $\left(\mathrm{mmol} \mathrm{m}^{-2}\right)$ & 0.024 & 0.026 & 0.025 & 0.025 & 0.025 \\
\hline Leaf $\mathrm{N}$ content / dry mass $\left(\mathrm{mmol} \mathrm{g}^{-1}\right)$ & 2.18 & 1.86 & 1.82 & 1.26 & 1.39 \\
\hline $\mathrm{C} / \mathrm{N}$ in leaf biomass $\left(\mathrm{g} \mathrm{g}^{-1}\right)$ & 31.4 & 35.8 & 41.3 & 59.8 & 58.1 \\
\hline $\mathrm{C} / \mathrm{N}$ in leaf litter $\left(\mathrm{g} \mathrm{g}^{-1}\right)$ & 28.6 & 47.8 & 48.0 & 59.9 & 61.9 \\
\hline \multicolumn{6}{|l|}{ Roots } \\
\hline Mean fine root longevity (months) ${ }^{2}$ & 11.2 & n.d. & 15.3 & n.d. & 8.4 \\
\hline $\mathrm{N}$ pool in root biomass $\left(\mathrm{Mg} \mathrm{ha}^{-1}\right)$ & 0.053 & 0.091 & 0.053 & 0.055 & 0.059 \\
\hline $\mathrm{C} / \mathrm{N}$ in fine root biomass (organic layers) & 23.2 & 29.1 & 43.4 & 55.2 & 91.1 \\
\hline $\mathrm{C} / \mathrm{N}$ in fine root litter (organic layers) & 23.6 & 26.9 & 33.1 & 44.2 & 60.1 \\
\hline \multicolumn{6}{|l|}{ Ratios } \\
\hline Fine root/leaf bi & 0.39 & 0.70 & 0.63 & 1.20 & 2.98 \\
\hline Stem wood increment per wood mass (\%) & 1.0 & 1.0 & 0.5 & 0.2 & 0.1 \\
\hline Coarse root growth per coarse root biomass (\%) & 0.6 & 2.6 & 1.2 & 0.7 & 1.7 \\
\hline BGB/AGB ratio & 0.11 & 0.22 & 0.15 & 0.39 & 0.56 \\
\hline ANPP per AGB (\%) & 3.7 & 5.3 & 5.3 & 3.9 & 2.5 \\
\hline BNPP per BGB $(\%)^{3}$ & 7.6 & 10.9 & 12.3 & 10.1 & 16.4 \\
\hline NPP per tree biomass $(\%)^{3}$ & 4.1 & 6.3 & 6.2 & 5.4 & $\begin{array}{r}7.4 \\
(4.7)\end{array}$ \\
\hline
\end{tabular}


1 Figure 1: Topographic map of the study area with its location in the south of Ecuador, position of

2 the study sites \#1-5, the "Estación Científica San Francisco" (ECSF) and its protected "Reserva

3 Biológica San Francisco" RBSF, showing altitudinal belts from $<1000$ to $>3500 \mathrm{~m}$ a.s.l. The

4 dotted line indicates the border of Podocarpus National Park, in black the province capitals Loja

5 and Zamora.

7 Figure 2: Aboveground $(\mathrm{A}-\mathrm{D})$ and belowground $(\mathrm{E}-\mathrm{H})$ biomass and production fractions in

8 their dependence on elevation in tropical mountain forests. Data compiled from a literature survey

9 of pan-tropical mountain transect studies and several single plots. Data points from a given

10 transect were connected with dotted lines for clarity. Bold lines indicate the regression lines of

11 linear or simple non-linear regression analyses covering all transects. For belowground biomass

12 (BGB), the regression analysis was conducted separately for data on total root and on fine root

13 biomass. In the graphs $\mathrm{G}$ and $\mathrm{H}$, the fine root production at $3060 \mathrm{~m}$ in the Ecuador transect was

14 estimated by extrapolating from the four lower stands. Ecuador - own data; Malaysia - Kitayama

15 \& Aiba (2002); Puerto Rico - Weaver \& Murphy (1990) and Wang et al. (2003); Hawaii - Raich

16 et al. (1997), Indonesia - Culmsee et al. (2010).

17

18 Figure 3: Stem wood production (A) and LAI (B), and their dependence on annual mean air

19 temperature in tropical mountain forests. Data compiled from a literature survey of pan-tropical mountain transect studies and several single plot studies. The vertical line indicates the elevation 
1 Figure 4: Above- and belowground trend lines of tree biomass and productivity extrapolated 2 toward the actual tree line. A) The intersection point of the AGB and BGB curves coincides well 3 with the position of the alpine tree line. B) Regression lines of ANPP and BNPP in relation to the 4 actual position of the alpine tree line at 3200-3400 m elevation. 
$1 \quad$ Fig.1

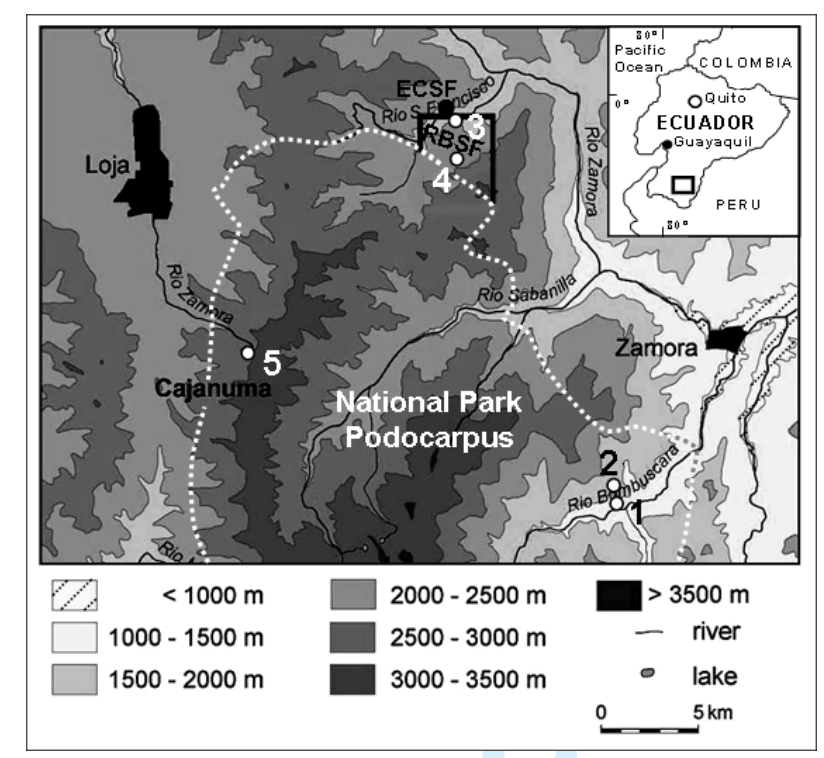

2 
$1 \quad$ Fig.2

2
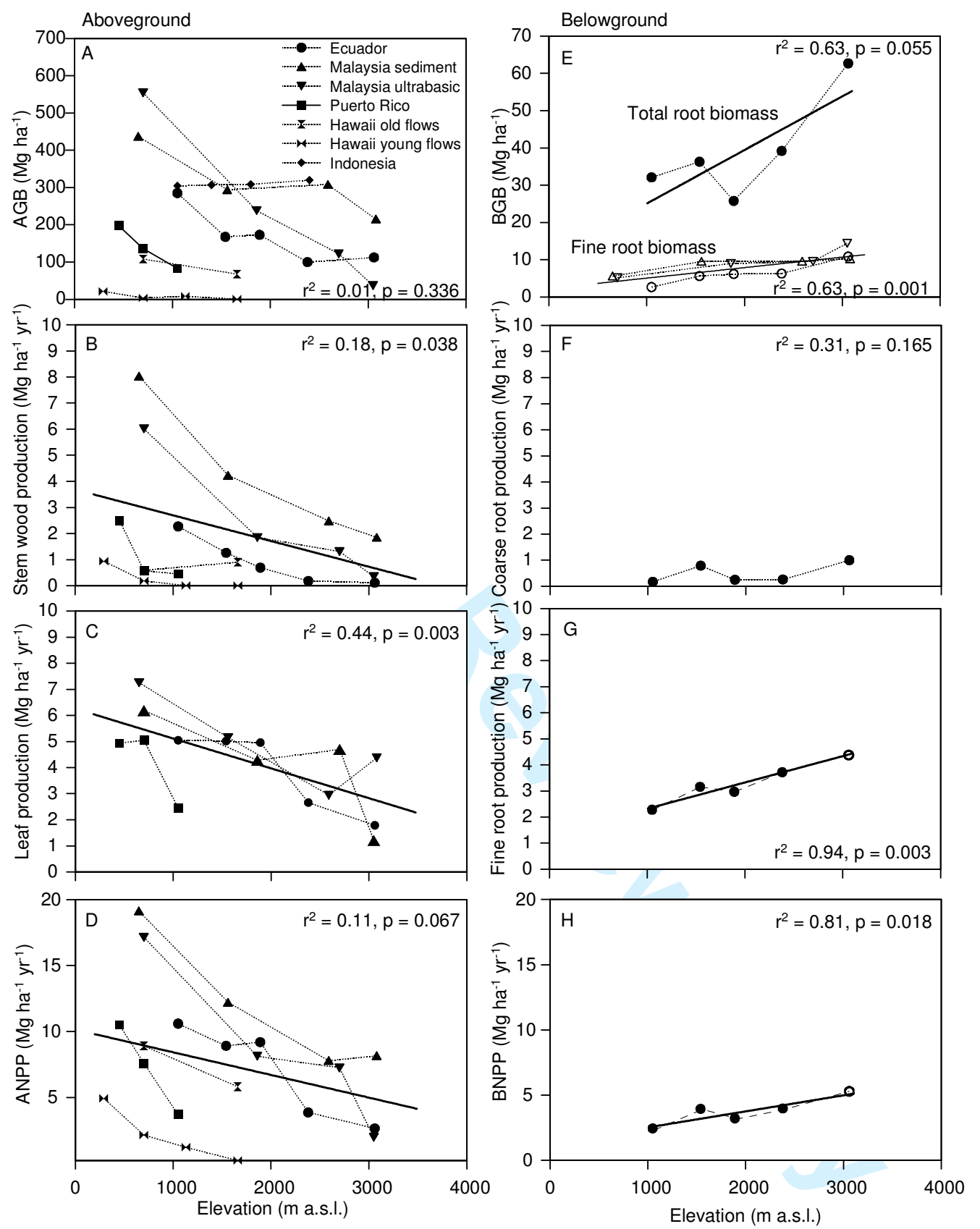
$1 \quad$ Fig. 3
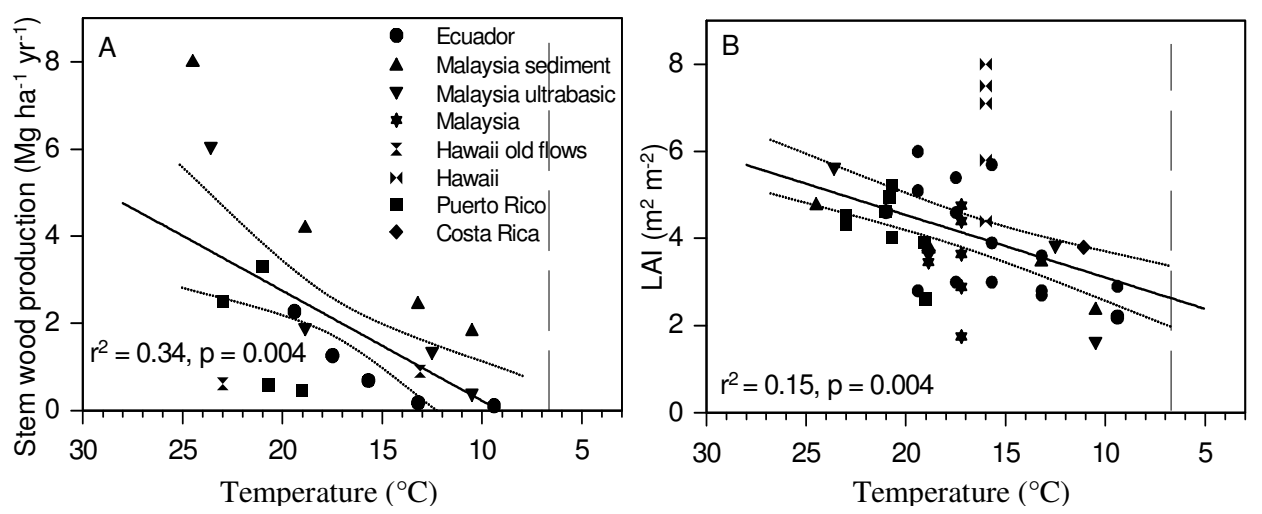
$1 \quad$ Fig. 4
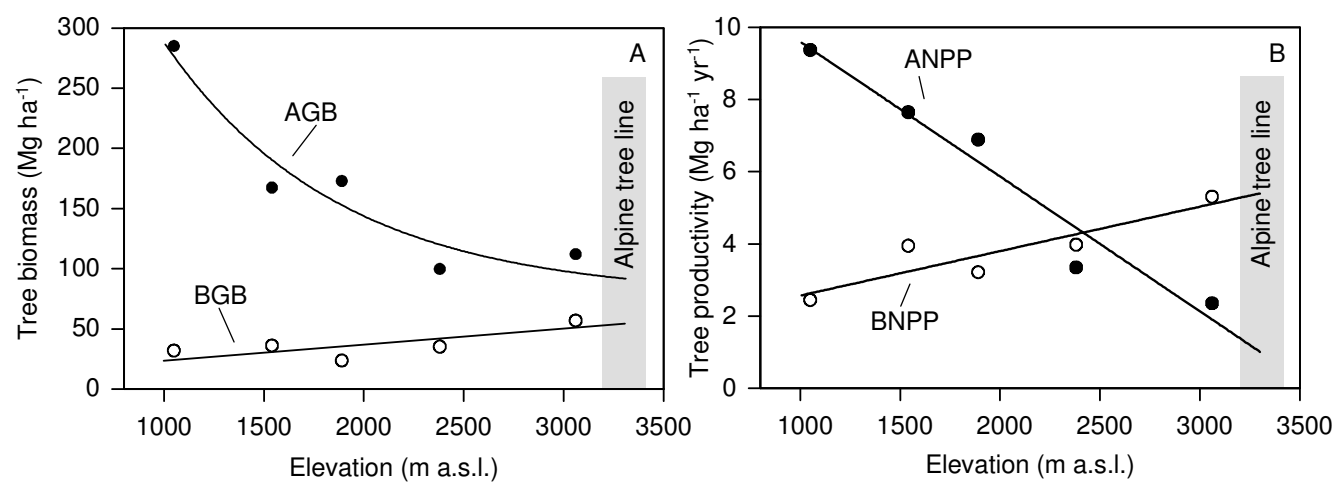